\title{
On-farm evaluation of the effect of metabolic diseases on the shape of the lactation curve in dairy cows through the MilkBot lactation model
}

\author{
M. Hostens, ${ }^{\star 1}$ J. Ehrlich, † B. Van Ranst, ${ }^{*}$ and G. Opsomer ${ }^{\star}$ \\ *Department of Reproduction, Obstetrics and Herd Health, Faculty of Veterinary Medicine, Ghent University, Salisburylaan 133, \\ 9820 Merelbeke, Belgium \\ †Dairy Veterinarians Group, 832 Coot Hill Rd., Argyle, NY 12809
}

\section{ABSTRACT}

The effects of metabolic diseases (MD) occurring during the transition period on milk production of dairy cows have been evaluated in many different ways, often with conflicting conclusions. The present study used a fitted lactation model to analyze specific aspects of lactation curve shape and magnitude in cows that avoided culling or death in the first $120 \mathrm{~d}$ in milk (DIM). Production and health records of 1,946 lactations in a 1-yr follow-up study design were collected from a transition management facility in Germany to evaluate both short- and long-term effects of MD on milk production. Milk production data were fitted with the nonlinear MilkBot lactation model, and health records were used to classify cows as healthy $(\mathrm{H})$, affected by one $\mathrm{MD}$ (MD), or by multiple MD (MD+). The final data set contained 1,071 H, $348 \mathrm{MD}$, and $136 \mathrm{MD}+$ cows, with distinct incidences of $3.7 \%$ twinning, $4.8 \%$ milk fever, $3.6 \%$ retained placenta, $15.4 \%$ metritis, $8.3 \%$ ketosis, $2.0 \%$ displaced abomasum, and $3.7 \%$ mastitis in the first 30 DIM. The model containing all healthy and diseased cows showed that lactations classified as $\mathrm{H}$ had milk production that increased faster (lower ramp) and also declined faster (lower persistence) compared with cows that encountered one or more metabolic problems. The level of production (scale) was only lowered in $\mathrm{MD}+$ cows compared with $\mathrm{H}$ and $\mathrm{MD}$ cows. Although the shape of the lactation curve changed when cows encounter uncomplicated (single) MD or complicated MD (more than one MD), the slower increase to a lower peak seemed to be compensated for by greater persistency, resulting in the overall 305-d milk production only being lowered in MD+ cows. In the individual disease models, specific changes in the shape of the lactation curve were found for all MD except twinning. Milk fever, retained placenta, ketosis, and mastitis mainly affected the lactation curve when accompanied

Received August 1, 2011.

Accepted February 2, 2012.

${ }^{1}$ Corresponding author: Miel.Hostens@UGent.be by another $\mathrm{MD}$, whereas metritis and displaced abomasum affected the lactation curve equally with or without another MD. Overall, 305-d milk production was decreased in complicated metritis $(10,603 \pm 50 \mathrm{~kg}$ vs. $10,114 \pm 172 \mathrm{~kg}$ ). Although care should be taken in generalizing conclusions from a highly specialized transition management facility, the current study demonstrated that lactation curve analysis may contribute substantially to the evaluation of both short- and longterm effects of metabolic diseases on milk production by detecting changes in the distribution of production that are not apparent when only totals are analyzed.

Key words: cow, transition period, lactation curve, metabolic disease

\section{INTRODUCTION}

The transition period, generally defined as the time span from 3 wk before until 3 wk after calving, has been the focus of a lot of applied research during the last decades (Drackley, 1999; LeBlanc, 2010). As most metabolic diseases (MD) occur in this stage of lactation, long-term effects on milk production and subsequent profitability can be influenced tremendously during this short period. New feeding and management practices have focused on finding the optimal ration and management strategies to achieve maximal production with the lowest incidence of $\mathrm{MD}$, albeit with variable success. One of the strategies includes the development of special high-needs barns for dry and fresh cow management, so-called transition management facilities (TMF). In these barns, special efforts have been made on housing, processing, and monitoring of dry and fresh cows to optimally transfer the cows to the milking barn when freshened for approximately $2 \mathrm{wk}$, having a stable milk production level and being free from clinical illness (Fetrow et al., 2004). In addition to the specifically adapted facilities, most TMF are equipped with an extensive software package generating a vast amount of high-quality data on the transition period, creating opportunities for researchers to investigate the withinherd effect of, for example, MD on milk production. 
Short- and long-term effects of MD on the lactation curve have been thoroughly described by Fourichon et al. (1999) but overall, studies have yielded conflicting results complicated by the very diverse approaches to the summarization of milk production. Short-term effects on milk production have been evaluated by comparing daily milk production before and after the clinical diagnosis (Detilleux et al., 1997), within the first 60 (M60; Sheldon et al., 2004) or 100 DIM (van Werven et al., 1992), whereas long-term effects have been described by analyzing 305-d milk production (M305; Dubuc et al., 2011) or overall lactation performance (Bigras-Poulin et al., 1990). One other reason for conflicting outcomes might be the use of different statistical methods, which has a major determinant effect on the interpretation of the data. Fourichon et al. (1999) discussed the difficulties of comparing diseased versus nondiseased animals. The higher culling rate in lower producing diseased animals generally results in a loss of data and possible underestimation of the disease effect (Bartlett et al., 1997), whereas the definition, severity, and interrelationships of transition diseases require controlling for bias when estimating the effect on milk production (Rajala and Grohn, 1998).

Lactation curve models have been used to model residuals between predicted and observed milk yield in healthy and diseased animals (Lucey et al., 1986; Rowlands and Lucey, 1986). Ehrlich (2011) described a novel nonlinear lactation model that can be fitted to milk production data to summarize an individual lactation as a set of 4 fitted parameter values, each of which corresponds to a specific aspect of lactation curve shape or magnitude. It is hypothesized that fitted parameter values may be more sensitive to the effects of MD than raw production data because, like M305, parameters are attributes of the lactation as a whole but each parameter relates to a specific aspect of the curve.

Because overall herd profitability is driven mainly by the quantity of milk produced by the proportion of cows that stay in the herd (Ducrocq et al., 1988), the aim of the present study was to use a fitted lactation curve model, summarizing all milk recording data in the lactation, to estimate the short- and long-term effects in uncomplicated (without concurrent other MD) and complicated MD cows that avoided culling or death in the first 120 DIM.

\section{MATERIALS AND METHODS}

\section{Animals and Housing}

Production and health records covering all calvings during a 1-yr period (April 2009 to April 2010) from a 2,450 cow dairy herd in Mecklenburg-Vorpommern (Germany) were recorded using the on-farm computer system Dairy Comp 305 (Valley Ag Software, Tulare, CA). In 2009, the average milk production per lactation was $11,085 \mathrm{~kg} / \mathrm{cow}$ (3.64\% milk fat, $3.32 \%$ milk protein). Transition cows were housed in a newly designed TMF modeled after a prototype at the College of Veterinary Medicine of the University of Minnesota, which was described by Fetrow et al. (2004). This is the first such facility in Europe designed especially for cows in the transition period. Pens to house a maximum of 32 animals per group included sand-bedded freestalls and one headlock per stall. Heifers were transferred to the TMF $40 \mathrm{~d}$ before the expected parturition date and cows at dry-off to achieve a dry period of $42 \mathrm{~d}$. Cows and heifers were housed separately within the TMF until moved to the milking barns, typically between 10 and 21 DIM. Separate far-off, close-up, and fresh-cow diets were fed as a TMR once daily, with push-ups every $2 \mathrm{~h}$.

\section{Metabolic Disorders and Treatments}

In the TMF, all diagnoses and treatments were executed and documented according to specific protocols. Animals were monitored intensely for MD during the pre- and postpartum periods. All postpartum cows were examined routinely for temperature and urinary ketosis (Ketostix, Bayer AG, Leverkusen, Germany) and by vaginal and rectal exam until cows were moved to the milking barns with stable milk production and free from signs of disease. The fresh cow protocol immediately after calving involved an oral drench of $500 \mathrm{~mL}$ of propylene glycol (Bernd-Dieter, Dusseldorf, Germany) in $50 \mathrm{~L}$ of lukewarm water. All cows with parity $>1$ were also given $500 \mathrm{~mL}$ of a $38.0 \%$ calcium borogluconate solution intravenously (Calcilift Forte, Albrecht GmbH, Aulendorf, Germany). Cases of milk fever (MF), identified by cold ears and extremities, mild muscle tremor, decreased rumen motility, and inability to rise, near the time of calving, were treated intravenously for $3 \mathrm{~d}$ with $500 \mathrm{~mL}$ of $38.0 \%$ calcium borogluconate solution. Even though not an MD, twinning (TWIN) was included in the analysis because cows calving twins are at greater risk for many MD compared with cows calving singletons (Fricke, 2001). Retained placenta (RP) was diagnosed when fetal membranes were not expelled for at least $24 \mathrm{~h}$ postpartum. Uncomplicated cases of RP were not treated medically, but were closely monitored for other signs of disease in subsequent days. The diagnosis of metritis (METR) was indicated by depression and fever $\left(>39.5^{\circ} \mathrm{C}\right)$ with a purulent or fetid vaginal discharge detected by vaginal exam or rectal palpation. Cows with METR received ceftiofur hydrochloride i.m. 
for 3 consecutive days at a dose of $2.2 \mathrm{mg} / \mathrm{kg}$ of BW (Excenel RTU, Pfizer Animal Health GmbH, Berlin, Germany) and a single intrauterine infusion of oxytetracycline at a dose of $15 \mathrm{mg} / \mathrm{kg}$ of BW (Oxy-Sleecol 200 LA, Albrecht GmbH, Aulendorf, Germany). Recurrent, nonresponsive cases of METR were re-treated with an intrauterine infusion of oxytetracycline, a single i.v. injection of flunixin meglumine at a dose of $2.2 \mathrm{mg} / \mathrm{kg}$ of BW (Finadyne, Intervet Deutschland GmbH, Unterschleißheim, Germany), and i.m. procaine benzyl penicillin at a dose of $10,000 \mathrm{IU} / \mathrm{kg}$ of $\mathrm{BW}$ combined with neomycin sulfate at a dose of $5 \mathrm{mg} / \mathrm{kg}$ of BW (Neopen, Intervet Deutschland $\mathrm{GmbH}$ ) for 3 consecutive days. Ketosis (KET) was defined as a decline in feed intake and milk yield accompanied by urinary ketone bodies exceeding $500 \mu \mathrm{mol} / \mathrm{L}$ (Ketostix, Bayer AG). Animals having urinary ketone bodies between 1,500 and 4,000 $\mu \mathrm{mol} / \mathrm{L}$ were treated with $500 \mathrm{~mL}$ of propylene glycol for 3 consecutive days. Animals with urinary ketones exceeding 4,000 $\mu \mathrm{mol} / \mathrm{L}$ were treated intravenously with $500 \mathrm{~mL}$ of a $40 \%$ glucose solution (B. Braun, Melsungen, Germany), $40 \mathrm{~mL}$ of a vitamin B complex (Vitamin B-Komplex, Serumwerk Bernburg, Bernburg, Germany), and an i.m. injection of dexamethasone at a dose of $0.08 \mathrm{mg} / \mathrm{kg}$ of BW (Rapidexon, Albrecht $\mathrm{GmbH})$. The diagnosis of a left displacement of the abomasum (DA) was made when depressed feed intake and milk yield were accompanied by the characteristic tympanic resonance ("ping") during percussion of the left flank. The method of choice for correction of DA at the farm was the "roll-and-toggle" method as described by Newman et al. (2008) except for cases not eligible for roll-and-toggle (e.g., recurrent cases), in which case a laparoscopic abomasopexy was executed as described by Newman et al. (2008). Right displacement of the abomasum was not included in the present study because it is a less common disease occurring throughout lactation and therefore less associated with the transition period (Doll et al., 2009).

Even though mastitis is not an MD, the increased incidence of mastitis (MAST) shortly after parturition (Koivula et al., 2005) has been associated with impaired metabolic health in transition cows (Chagunda et al., 2006; Moyes et al., 2009), which has a major effect on short- and long-term milk production (Wilson et al., 2008). Cows with clinical signs of MAST, such as udder inflammation and abnormal milk (IDF, 1997; Chagunda et al., 2006), were first identified by farm staff in the milk parlor and confirmed later by the herd manager. All cows having a MAST event before 30 DIM were included in the analysis to restrict the analysis to transition period disease. Affected cows were treated according to the herd protocol. Animals having mild
MAST were treated with an intramammary application of $88.8 \mathrm{mg}$ of cefquinome sulfate per infected quarter (Cobactan LC, Intervet Deutschland $\mathrm{GmbH}$ ) for 3 consecutive days. In case of a severe MAST, the previous protocol was extended with cefquinome intramuscularly at a dose rate of $1 \mathrm{mg} / \mathrm{kg}$ of BW (Cobactan 2.5\%, Intervet Deutschland $\mathrm{GmbH}$ ) and a single intravenous injection of flunixin meglumine at a dose of $2.2 \mathrm{mg} / \mathrm{kg}$ of BW (Finadyne, Intervet Deutschland $\mathrm{GmbH}$ ).

\section{Data Collection and Handling}

Between April 2009 and April 2010, data were collected from 1,946 calvings within the herd. Disease events were diagnosed by trained dairy personnel. Monthly DHIA milk production data and all disease events were meticulously recorded by the herdsmen using DC305. First-, second-, and older-parity cows accounted for $27.9,28.5$, and $43.8 \%$, respectively, of the primary data set. To accurately estimate the lactation curve of surviving cows and include at least 3 monthly milk recordings in the lactation model, cows with insufficient milk recording data $(2.3 \%, \mathrm{n}=45)$ and cows that died $(3.6 \%, \mathrm{n}=70)$ or were sold before 120 DIM $(14.2 \%, \mathrm{n}=276)$ were excluded from the primary data set. This resulted in 1,555 cows in the secondary data set. First-, second-, and older-parity cows accounted for $29.5,31.6$, and $38.9 \%$, respectively, of the secondary data set. The average DIM and range of the first recorded MD event in this data set are represented in Table 1.

Subsequently, cows were classified as being healthy $(\mathbf{H})$ or suffering from one (MD) or more (MD+) metabolic problems. To allow for an analysis within each transition disease, animals without any recorded event for TWIN, MF, RP, METR, KET, DA, or MAST were classified as being healthy. Animals with one single MD were classified in the appropriate uncomplicated MD (TWIN, MF, RP, METR, KET, DA, or MAST), whereas animals that suffered from one MD that was complicated with another concomitant MD were classified as complicated MD (MD+). For example, within the MF analysis, all animals without any MD event were classified as $\mathrm{H}$, all animals that only suffered from MF were classified as MF, and animals that suffered from $\mathrm{MF}$ in combination with another MD were classified as $\mathrm{MF}+$. Within each MD+ group, no further distinction was made between diseases. For example, animals with RP that had subsequently encountered KET and animals that subsequently encountered METR were both classified as RP+.

The MilkBot lactation model, which can be expressed functionally as 
Table 1. Average DIM for selected metabolic problems

\begin{tabular}{|c|c|c|c|c|}
\hline \multirow{2}{*}{$\begin{array}{l}\text { Metabolic } \\
\text { problem }\end{array}$} & \multicolumn{3}{|c|}{ DIM } & \multirow{2}{*}{$\underset{\text { (no.) }}{\text { Animals }}$} \\
\hline & Mean \pm SE & Median & Range & \\
\hline Twin & $1.00 \pm 0.00$ & 1 & - & 58 \\
\hline Milk fever & $1.32 \pm 0.13$ & 1 & $0-6$ & 74 \\
\hline Retained placenta & $2.17 \pm 0.20$ & 2 & $1-8$ & 53 \\
\hline Metritis & $7.57 \pm 0.19$ & 8 & $0-15$ & 239 \\
\hline Ketosis & $8.29 \pm 0.64$ & 6 & $0-46$ & 129 \\
\hline Displaced abomasum & $13.96 \pm 1.58$ & 11 & $4-38$ & 31 \\
\hline Mastitis & $14.77 \pm 1.11$ & 14 & $0-30$ & 71 \\
\hline
\end{tabular}

$$
Y(t)=a\left(1-\frac{e^{\frac{c-t}{b}}}{2}\right) e^{-d t}
$$

(Ehrlich, 2011), was used to summarize the magnitude and shape of each individual lactation curve, where $Y(t)$ is total daily milk production on day $t$ of the lactation, and parameters $a, b, c$, and $d$ control the shape of the curve. Monthly DHIA milk weights were exported from Dairy Comp 305 and fitted to the MilkBot model using a proprietary maximum likelihood fitting algorithm (DairySight LLC, Argyle, NY). The fitted parameter values generated by this process quantify magnitude and selected aspects of the shape of each curve. Specifically, lactation scale is measured by the $a$ parameter in the MilkBot function. It is a simple linear scalar with equal influence at all stages of lactation. The parameter $b$, called the ramp parameter, measures the steepness of the postparturient increase in production, so it is most influenced by changes in early lactation. Higher ramp values correspond to a slower increase in production. The decay parameter, $d$, relates to senescence and loss of productive capacity and is influenced by cumulative changes in productive capacity occurring throughout the lactation. As a first-order rate constant, decay can be expressed as half-life, called persistence, corresponding approximately to the time in days for production to decrease by half in late lactation (Ehrlich, 2011). Finally, the MilkBot offset parameter, $c$, is the theoretical offset between parturition and the physiological start of lactation. Normal variability in the offset parameter is expected to be small and practically undetectable without daily milk weights in the first days of lactation, so the offset value was fixed to 0 in the present study. Recent work (Cole et al., 2012) using the MilkBot model and the same fitting algorithm used in this study demonstrated high precision and low bias when used to project future milk production. This methodology allows scale, ramp, and persistence of individual lactations to be treated as independent variables in statistical models, along with the derived variables time to peak milk (TPEAK), peak milk (MPEAK), cumulative 60-d milk yield (M60), and cumulative 305-d milk yield (M305), which are easily calculated directly from MilkBot parameter values (Ehrlich, 2011).

\section{Statistical Analysis}

Descriptive statistics were done using the MEANS and FREQ procedure in SAS for Windows (version 9.2, 2010; SAS Institute Inc., Cary, NC). To evaluate the DIM to culling or death, a Kaplan-Meier survival graph was constructed using the LIFETEST procedure in SAS (SAS Institute Inc.). To test equality over MD strata, the Peto and Wilcoxon test was used to evaluate difference in the beginning of the survival curves, whereas the log-rank test was used to evaluate difference in the tail of the curves (Hosmer and Lemeshow, 2008). Survival rates are reported with their $95 \%$ confidence intervals for the Kaplan-Meier estimates. To evaluate the effect of MD on the lactation curve, all MilkBot parameters and calculated production metrics were subsequently analyzed separately using PROC MIXED from SAS version 9.2 for Windows (SAS Institute Inc.). The distribution of all variables was checked to approximate the Gaussian distribution. The log-transformation was carried out for TPEAK before analysis. The statistical model contained fixed effects for MD, parity, and the interaction between MD and parity. Metabolic disease least squares means and contrasts were computed using the LSMEANS and LSMESTIMATE options. Significance and tendency were declared at $P<0.05$ and 0.05 $<P<0.1$ respectively. Data are reported as model least squares means with standard errors except for TPEAK. Results from the TPEAK model were back-transformed and reported with $95 \%$ confidence intervals.

\section{RESULTS}

In the first analysis, the overall survival rate at 120 DIM was $82 \%(80-84 \%)$, which differed between the MD strata $(P<0.0001)$. The survival rate at 120 DIM was estimated at $87 \%(85-89 \%)$ for $\mathrm{H}$ compared with 
Table 2. Incidence (\%) of selected metabolic problems by parity

\begin{tabular}{|c|c|c|c|c|c|}
\hline \multirow[b]{2}{*}{ Metabolic problem } & \multicolumn{4}{|c|}{ Parity } & \multirow{2}{*}{$\underset{(\text { no. })}{\text { Animals }}$} \\
\hline & 1 & 2 & $>2$ & All & \\
\hline Twin & 0.65 & 4.48 & 5.45 & 3.73 & 58 \\
\hline Milk fever & 0.00 & 1.63 & 10.91 & 4.76 & 74 \\
\hline Retained placenta & 3.49 & 2.85 & 3.80 & 3.56 & 53 \\
\hline Metritis & 29.41 & 11.00 & 8.26 & 15.37 & 239 \\
\hline Ketosis & 8.28 & 4.28 & 11.57 & 8.30 & 129 \\
\hline Displaced abomasum & 1.74 & 1.43 & 2.64 & 1.99 & 31 \\
\hline Mastitis & 3.70 & 4.28 & 5.45 & 4.57 & 71 \\
\hline All & 37.47 & 20.77 & 34.71 & 31.13 & \\
\hline
\end{tabular}

$75 \%(71-79 \%)$ and $67 \%(60-73 \%)$ for $\mathrm{MD}$ and $\mathrm{MD}+$, respectively (Figure 1). After exclusion of the cows that died or were culled before 120 DIM, $68.9 \% \mathrm{H}$ cows ( $=1,071), 22.4 \% \mathrm{MD}$ cows $(\mathrm{n}=333)$, and $8.7 \% \mathrm{MD}+$ cows $(\mathrm{n}=136)$ were included in the second analysis. The overall lactation incidence was highest for METR and KET occurring in $15.4 \%(\mathrm{n}=239)$ and $8.3 \%(\mathrm{n}$ $=129$ ) of calvings, respectively (Table 2). The lowest overall lactation incidence of $1.99 \%$ was recorded for DA $(\mathrm{n}=31)$.

Results from the model that included all MD are represented in Table 3. MilkBot ramp and decay values were different between $\mathrm{H}, \mathrm{MD}$, and $\mathrm{MD}+$, whereas the MilkBot scale was only lowered in $\mathrm{MD}+(P<$ 0.0001). Lactations of $\mathrm{H}$ cows showed a faster increase in production (lower ramp) and faster decline (lower persistence, higher decay, $P<0.0001$ ) compared with lactation curves of MD or MD+ cows. The scale of production was only diminished in $\mathrm{MD}+$ cows compared with $\mathrm{H}$ and $\mathrm{MD}$. The significant interaction term for both ramp and scale between MD and parity revealed a more severe effect of MD on ramp in older cows (parity $>2$ ) next to a remarkably decreased scale in $\mathrm{MD}+$ second-parity cows compared with $\mathrm{H}$. The lactation curves corresponding to the parameter values in Table 3 are separately shown for parity 1 (Figure 2), parity 2 (Figure 3 ), and parity $>2$ (Figure 4 ). Because of the change in the lactation curve, TPEAK increased $(P$ $<0.0001$ ) between $\mathrm{H}, \mathrm{MD}$, and $\mathrm{MD}+$, whereas both MPEAK $(P<0.0001)$ and M60 $(P<0.0001)$ were only

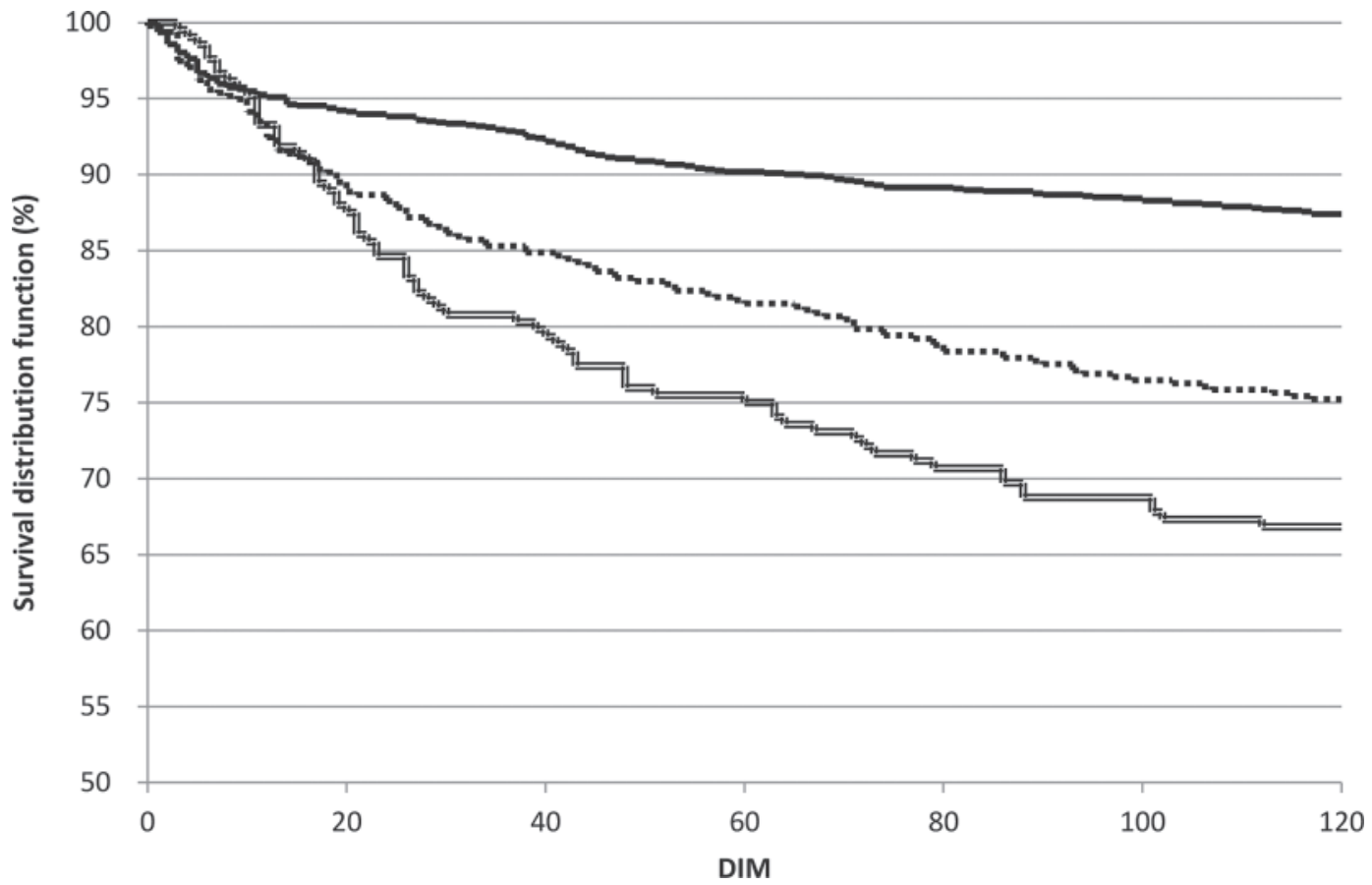

Figure 1. Kaplan-Meier survival distribution functions for time to a died or sold event of cows that encountered no metabolic problem during the transition period (solid line), cows that encountered 1 metabolic problem during the transition period (dotted line), and cows that encountered $>1$ metabolic problem during the transition period (double line). 
decreased when cows encountered $\mathrm{MD}+$, especially in $>1$ parity cows. The overall M305 was equal in $\mathrm{H}$ and MD cows but lowered in MD+ $(P=0.029)$, especially in second-parity cows $(P=0.037$ for the interaction term).

Complicated twinning (TWIN+) only tended to affect the scale $(P=0.061)$, which resulted in TWIN+ animals having decreased MPEAK $(P=0.027)$ and M60 $(P=0.012)$ compared with $\mathrm{H}$ animals (Table 4); TPEAK was delayed in older-parity TWIN+ cows compared with $\mathrm{H}$ cows (95\% CI: $42-51$ vs. $38-39$ d).

The incidence of MD per parity in the primary data set revealed that no first-parity cow suffered an MF event, so first-parity animals were excluded from the MF model to have the statistical model converge. Because of the low number of second-parity MF cows, second- and third-parity cows were grouped to avoid loss of information. The MF model included $784 \mathrm{H}$, $49 \mathrm{MF}$, and $25 \mathrm{MF}+$ animals with parity $>1$ (Table $5)$. Milk fever altered the lactation curve mainly when accompanied by another MD (i.e., in MF+ cows). The ramp parameter increased (slower increase in milk production) in MF+ versus $\mathrm{H}$ and MF $(P<0.0001)$. Scale was decreased $(P=0.0015)$ and persistency increased $(P=0.0005)$ for $\mathrm{MF}+$ versus $\mathrm{H}$ and $\mathrm{MF}$ cows. Finally, TPEAK was delayed $(P<0.0001)$ and milk production variables MPEAK $(P=0.0005)$ and M60 $(P<$ $0.0001)$ were lower in $\mathrm{MF}+$ compared with $\mathrm{H}$ and $\mathrm{MF}$ cows, whereas M305 was not affected $(P=0.23)$. The increased scale in parity 2 to $3 \mathrm{MF}$ cows tended to be significant $(P=0.080)$, which was reflected in both MPEAK and M60.

In the RP model, the ramp parameter was not altered $(P=0.33)$. The scale parameter decreased in $\mathrm{RP}+$ versus $\mathrm{H}$ cows $(P=0.0054)$, especially in second-parity $\mathrm{RP}+\operatorname{cows}(P=0.020)$. The TPEAK was delayed in $\mathrm{RP}+$ compared with $\mathrm{H}$ cows $(P=0.0028)$, whereas $\operatorname{MPEAK}(P=0.0055)$ and M60 $(P=0.0015)$ were decreased in $\mathrm{RP}+$ compared with both $\mathrm{RP}$ and $\mathrm{H}$ cows (Table 6). Persistency was higher for $\mathrm{RP}+$ cows compared with $\mathrm{H}$ cows $(P=0.0039)$, and M305 tended to differ between RP $(11,553 \pm 477 \mathrm{~kg})$ and $\mathrm{RP}+(10,265$ $\pm 268 \mathrm{~kg})$ animals $(P=0.063)$.

Metritis influenced all MilkBot parameters. Ramp differed between $\mathrm{H}$ and METR or METR + cows ( $P$ $<0.0001)$, resulting in the steepest increase in milk production in $\mathrm{H}$ cows. The $\mathrm{H}$ cows had a higher scale compared with METR + cows $(P<0.0001)$. This resulted in a delayed TPEAK $(P<0.0001)$ and decreased MPEAK $(P<0.0001)$ and M60 $(P<0.0001)$ in cows suffering from METR or METR+ compared with $\mathrm{H}$. As can be seen in Table 7, cows experiencing uncomplicated (METR) or complicated metritis (METR+) were more persistent in their lactation compared with $\mathrm{H}$ cows
$(P<0.0001)$. Despite this persistency compensation, M305 was decreased by $489.6 \mathrm{~kg}$ (95\% CI: $138.0-841.1$ $\mathrm{kg}$ ) in METR + cows compared with $\mathrm{H}$. The interaction term in $\operatorname{ramp}(P<0.0001)$, scale $(P=0.0096)$, TPEAK $(P=0.0012)$, MPEAK $(P=0.0002), \operatorname{M60}(P$ $<0.0001)$, and M305 $(P=0.044)$ revealed a lack of effect of METR on the shape of the lactation curve and milk production estimates in first-parity cows.

Affected cows had a delayed TPEAK in both KET (95\% CI: 54-62 d) and KET+ (95\% CI: 59-67 d) compared with $\mathrm{H}$ cows (95\% CI: $50-52$ d) because of a slower milk production inclination $(P<0.0001)$, especially in older cows $(P<0.0001)$. Scale of the lactation was higher in $\mathrm{H}$ compared with $\mathrm{KET}+\operatorname{cows}(P=$ $0.014)$, resulting in similar differences for MPEAK $(P$ $=0.0027)$ and M60 $(P<0.0001)$. Older KET cows had a higher lactation scale $(P=0.033)$ and concomitant increased MPEAK $(P=0.0002)$ and M60 $(P=0.0003)$ compared with older KET + cows. The KET + cows had a higher persistency compared with $\mathrm{H}$ cows $(P=$ $0.0003)$. Overall, M305 was not altered by $\operatorname{KET}(P=$ 0.64 , Table 8).

Because of the low number of DA $(\mathrm{n}=31)$, first- and second-parity cows were grouped to avoid loss of information (Table 9). A slower increase in milk production $(P<0.0001)$ and longer persistency in DA + cows compared with their healthy counterparts combined with a lower scale $(P=0.037)$ resulted in a decreased MPEAK $(P=0.0041)$ and M60 $(P=0.0007)$ but overall equal M305 $(P=0.77)$. The interaction term showed that older DA cows ( $>2$ parity) also had a slower milk increase compared with $\mathrm{H}(P=0.0008)$. Overall TPEAK was delayed in both DA (95\% CI: 48-82 d) and DA+ (95\% CI: $57-77 \mathrm{~d})$ cows compared with $\mathrm{H}$ cows $(95 \%$ CI: $43-45 \mathrm{~d} ; P<0.0001)$.

Mastitis during early lactation $(<30$ DIM) decreased the scale in MAST + cows compared with $\mathrm{H}$ and MAST cows $(P=0.012)$. Both MPEAK $(P=0.013)$ and M60 $(P=0.0081)$ were similarly decreased in MAST+ cows. Because of a decreased decay in MAST + cows compared with $\mathrm{H}(P=0.031)$, no overall differences in M305 could be found $(P=0.18)$. The TPEAK was delayed $5 \mathrm{~d}$ in MAST + cows compared with $\mathrm{H}(P=$ 0.041). As shown in Table 10, no interaction of MAST with parity could be found for any of the outcome variables.

\section{DISCUSSION}

Wallace et al. (1996) were the first to report an overall daily milk production decrease of $7.2 \mathrm{~kg}$ related to transition health disorders during the first $20 \mathrm{~d}$ postpartum. To our knowledge, we are the first to describe the effect of multiple MD on the shape of the entire lactation 
Table 3. The effect of metabolic problems on MilkBot parameter values and calculated metrics for fitted individual lactation curves

\begin{tabular}{|c|c|c|c|c|c|c|c|c|c|c|}
\hline \multirow[b]{2}{*}{ Parameter $^{2}$} & \multirow[b]{2}{*}{ Parity } & \multicolumn{2}{|c|}{$\mathrm{H}$} & \multicolumn{2}{|c|}{$\mathrm{MD}$} & \multicolumn{2}{|c|}{$\mathrm{MD}+$} & \multicolumn{3}{|c|}{$P$-value ${ }^{3}$} \\
\hline & & Mean & SE & Mean & SE & Mean & SE & $\mathrm{MD}$ & INT & PAR \\
\hline \multirow[t]{4}{*}{ Ramp } & All & $23.40^{\mathrm{a}}$ & 0.20 & $25.11^{\mathrm{b}}$ & 0.36 & $26.95^{\mathrm{c}}$ & 0.56 & $<0.0001$ & $<0.0001$ & $<0.0001$ \\
\hline & 1 & $29.07^{\mathrm{x}}$ & 0.37 & $29.59^{\mathrm{x}}$ & 0.55 & $30.49^{\mathrm{x}}$ & 1.03 & & & \\
\hline & 2 & $21.41^{\mathrm{y}}$ & 0.32 & $21.99^{y}$ & 0.77 & $22.87^{\mathrm{y}}$ & 1.07 & & & \\
\hline & $>2$ & $19.71^{\mathrm{a}, \mathrm{z}}$ & 0.32 & $23.75^{\mathrm{b}, \mathrm{y}}$ & 0.52 & $27.48^{\mathrm{c}, \mathrm{x}}$ & 0.8 & & & \\
\hline \multirow[t]{4}{*}{ Scale } & All & $52.68^{\mathrm{a}}$ & 0.25 & $52.22^{\mathrm{a}}$ & 0.47 & $48.39^{\mathrm{b}}$ & 0.72 & $<0.0001$ & 0.0030 & $<0.0001$ \\
\hline & 1 & $41.66^{\mathrm{x}}$ & 0.48 & $41.98^{\mathrm{x}}$ & 0.71 & $41.25^{\mathrm{x}}$ & 1.33 & & & \\
\hline & 2 & $56.70^{\mathrm{a}, \mathrm{y}}$ & 0.41 & $54.51^{\mathrm{ab}, \mathrm{y}}$ & 1.00 & $49.62^{\mathrm{b}, \mathrm{y}}$ & 1.38 & & & \\
\hline & $>2$ & $59.69^{\mathrm{a}, \mathrm{z}}$ & 0.41 & $60.16^{\mathrm{a}, \mathrm{z}}$ & 0.67 & $54.29^{\mathrm{b}, \mathrm{y}}$ & 1.03 & & & \\
\hline \multirow[t]{4}{*}{ Decay } & All & $0.002506^{\mathrm{a}}$ & 0.000023 & $0.002385^{\mathrm{b}}$ & 0.000043 & $0.002138^{\mathrm{c}}$ & 0.000067 & $<0.0001$ & 0.49 & $<0.0001$ \\
\hline & 1 & $0.001383^{x}$ & 0.000045 & $0.001348^{\mathrm{x}}$ & 0.000065 & $0.001150^{x}$ & 0.000122 & & & \\
\hline & 2 & $0.002874^{\mathrm{y}}$ & 0.000038 & $0.002671^{\mathrm{y}}$ & 0.000092 & $0.002471^{\mathrm{y}}$ & 0.000128 & & & \\
\hline & $>2$ & $0.003262^{\mathrm{z}}$ & 0.000038 & $0.003135^{\mathrm{z}}$ & 0.000062 & $0.002795^{\mathrm{z}}$ & 0.000095 & & & \\
\hline \multirow[t]{4}{*}{ MPEAK (kg) } & All & $44.14^{\mathrm{a}}$ & 0.19 & $43.59^{\mathrm{a}}$ & 0.35 & $40.62^{\mathrm{b}}$ & 0.54 & $<0.0001$ & 0.0001 & $<0.0001$ \\
\hline & 1 & $36.23^{\mathrm{x}}$ & 0.36 & $36.58^{\mathrm{x}}$ & 0.53 & $36.53^{\mathrm{x}}$ & 0.99 & & & \\
\hline & 2 & $46.94^{\mathrm{a}, \mathrm{y}}$ & 0.31 & $45.45^{\mathrm{a}, \mathrm{y}}$ & 0.75 & $41.52^{\mathrm{b}, \mathrm{y}}$ & 1.03 & & & \\
\hline & $>2$ & $49.25^{\mathrm{a}, \mathrm{z}}$ & 0.31 & $48.75^{\mathrm{a}, \mathrm{z}}$ & 0.50 & $43.80^{\mathrm{b}, \mathrm{y}}$ & 0.77 & & & \\
\hline \multirow[t]{4}{*}{ M60 (kg) } & All & $2,409^{\mathrm{a}}$ & 11 & $2,365^{\mathrm{a}}$ & 19 & $2,180^{\mathrm{b}}$ & 30 & $<0.0001$ & 0.0001 & $<0.0001$ \\
\hline & 1 & $1.893^{\mathrm{x}}$ & 20 & $1,904^{\mathrm{x}}$ & 29 & $1.874^{\mathrm{x}}$ & 55 & & & \\
\hline & 2 & $2,600^{\mathrm{a}, y}$ & 17 & $2,505^{\mathrm{a}, \mathrm{y}}$ & 42 & $2,277^{\mathrm{b}, \mathrm{y}}$ & 58 & & & \\
\hline & $>2$ & $2,734^{\mathrm{a}, \mathrm{z}}$ & 17 & $2,686^{\mathrm{a}, \mathrm{z}}$ & 28 & $2,389^{\mathrm{b}, y}$ & 43 & & & \\
\hline \multirow{4}{*}{ M305 (kg) } & All & $10,603^{\mathrm{a}}$ & 50 & $10,659^{\mathrm{a}}$ & 92 & $10,226^{\mathrm{b}}$ & 143 & 0.029 & 0.037 & $<0.0001$ \\
\hline & 1 & $9,800^{\mathrm{x}}$ & 95 & $9,921^{\mathrm{x}}$ & 139 & 10,075 & 262 & & & \\
\hline & 2 & $10,994^{\mathrm{a}, \mathrm{y}}$ & 82 & $10,868^{\mathrm{ab}, \mathrm{y}}$ & 197 & $10,114^{\mathrm{b}}$ & 273 & & & \\
\hline & $>2$ & $11,017^{\mathrm{y}}$ & 81 & $11,189^{\mathrm{y}}$ & 133 & 10,489 & 203 & & & \\
\hline \multirow[t]{4}{*}{ TPEAK (d) } & All & $51^{\mathrm{a}}$ & $50-52^{4}$ & $55^{\mathrm{b}}$ & $53-56$ & $61^{\mathrm{c}}$ & $58-63$ & $<0.0001$ & 0.0001 & $<0.0001$ \\
\hline & 1 & $75^{\mathrm{x}}$ & $73-77$ & $77^{\mathrm{x}}$ & $74-80$ & $85^{\mathrm{x}}$ & 79-92 & & & \\
\hline & 2 & $46^{y}$ & $45-47$ & $48^{y}$ & $45-51$ & $51^{y}$ & $47-56$ & & & \\
\hline & $>2$ & \multirow{2}{*}{\multicolumn{2}{|c|}{1,071}} & $44^{\mathrm{b}, \mathrm{y}}$ & $42-46$ & $51^{c, y}$ & $48-55$ & & & \\
\hline Animals (no.) & & & & $34 \varnothing$ & & \multicolumn{2}{|c|}{136} & & & \\
\hline
\end{tabular}

${ }^{\mathrm{a}-\mathrm{c}}$ Values within a row with different superscripts significantly differ.

${ }^{\mathrm{x}-\mathrm{z}}$ Values within a column with different superscripts significantly differ.

${ }^{1}$ Values are model least squares means for healthy $(\mathrm{H})$, affected by one metabolic disease (MD), or by multiple metabolic disease (MD+) cows.

${ }^{2}$ Scale $(a), \operatorname{ramp}(b)$, offset $(c=0)$, and decay $(d)$ parameters from the fitted MilkBot model can be expressed as $Y(t)=a\left(1-\frac{e^{\frac{c-t}{b}}}{2}\right) e^{-d t}$ in function of DIM $(t)$. MPEAK $=$ peak milk yield; M60 = cumulative 60 DIM milk yield; M305 = cumulative 305 DIM milk yield; TPEAK = time to peak milk yield.

${ }^{3}$ Effect of MD, parity (PAR), and their interaction (INT).

${ }^{4}$ For TPEAK, ranges indicate back-transformed 95\% CI. 


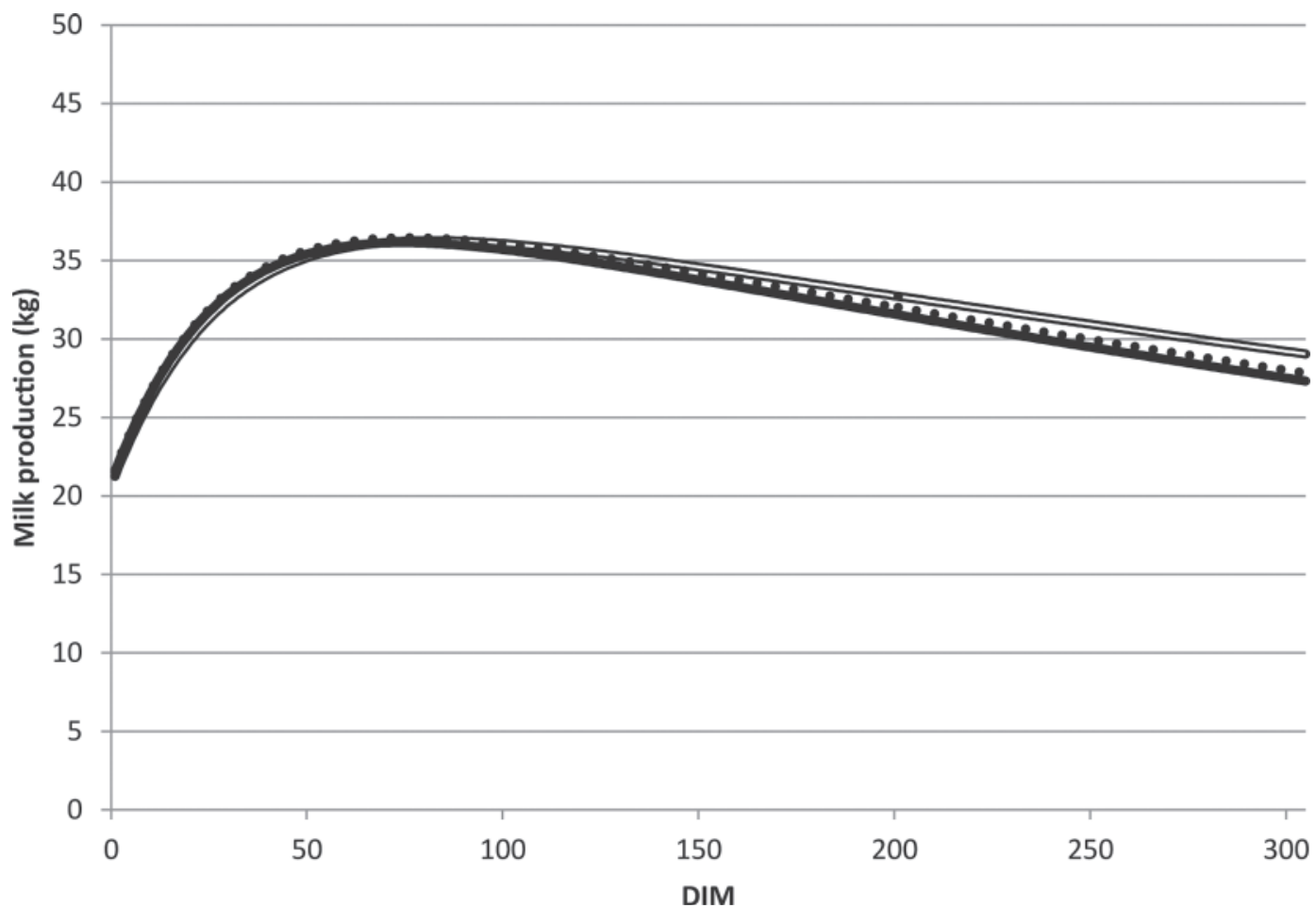

Figure 2. The effect of metabolic problems on lactation curve shape in first-lactation cows: cows that encountered no metabolic problems during the transition period (solid line), cows that encountered 1 metabolic problem during the transition period (dotted line), and cows that encountered $>1$ metabolic problem during the transition period (double line).

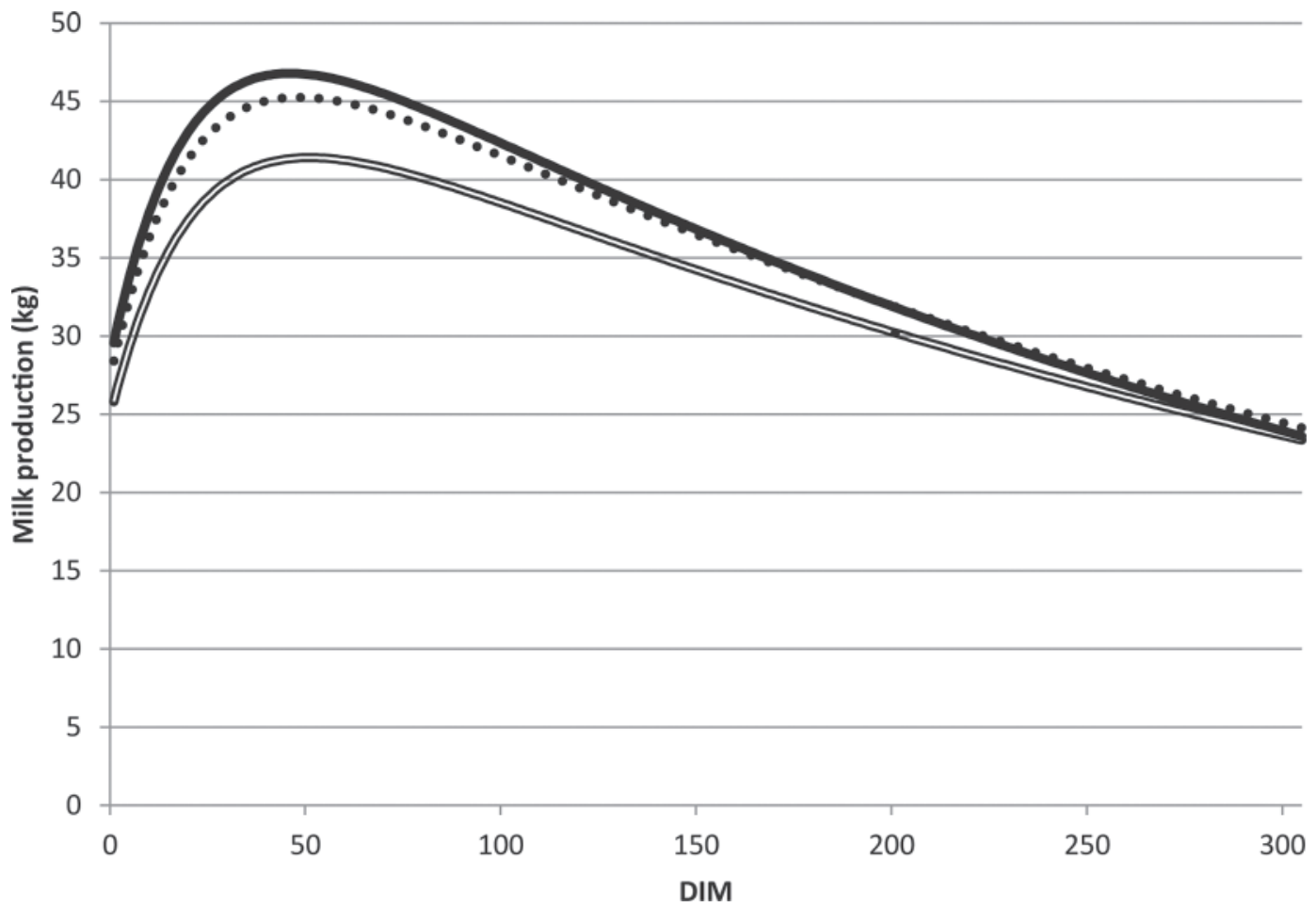

Figure 3. The effect of metabolic problems on lactation curve shape in second-lactation cows: cows that encountered no metabolic problems during the transition period (solid line), cows that encountered 1 metabolic problem during the transition period (dotted line), and cows that encountered $>1$ metabolic problem during the transition period (double line). 


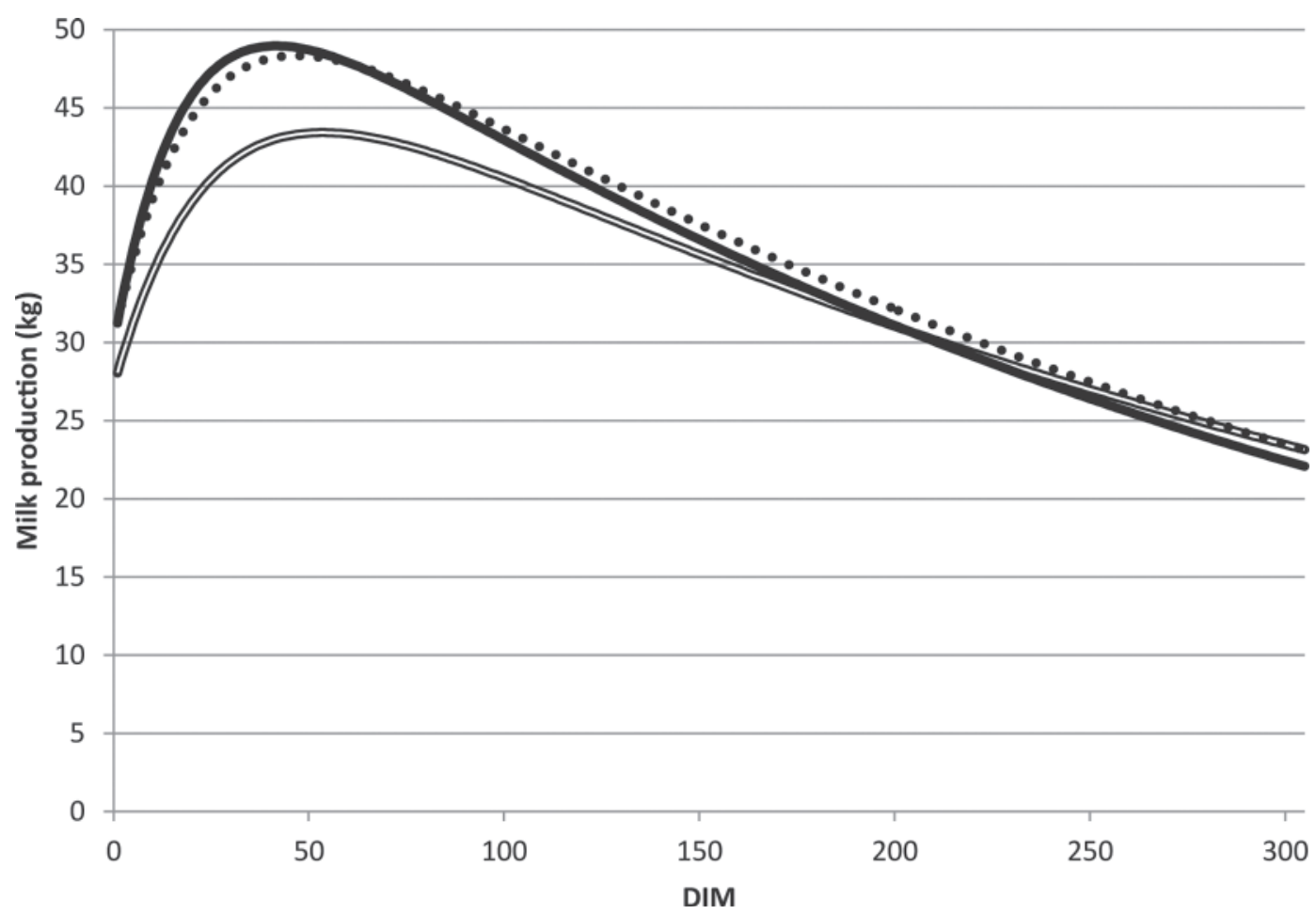

Figure 4. The effect of metabolic problems on lactation curve shape in third- or greater-lactation cows: cows that encountered no metabolic problems during the transition period (solid line), cows that encountered 1 metabolic problem during the transition period (dotted line), and cows that encountered $>1$ metabolic problem during the transition period (double line).

curve for cows that avoided culling or death during the first 120 DIM. Although the maximum likelihood algorithm used for fitting can exploit a priori information to achieve a solution from even a single data point, in that case the solution would be influenced by population means more than the data point. As a practical matter, to achieve reasonable estimates of the 3 parameters (scale, ramp, and decay) for individual lactations, at least 3 monthly test-days were needed. This required censoring lactations from the main data set in which the cow died or was culled before 120 DIM. This limitation reflects the actual on-farm situation where herd profitability is driven by the quantity of milk produced by the surviving proportion of cows in the herd (Ducrocq et al., 1988) and negatively influenced by culling (Essl, 1998; De Vries, 2006). The culling rate at 60 DIM in this study (13.6\%) was higher compared with data from Dechow and Goodling (2008), who found an average culling rate at 60 DIM of $6.8 \pm 4.6 \%$ in 2,574 dairy herds. A more recent study analyzing 107 large dairy farms revealed a culling rate at 60 DIM of $10.5 \%$, which is more comparable to our data (Schefers et al., 2010). Although the observation of increased culling rate in larger herds has been described previously (Hadley et al., 2006), differences in case definition of cull events and the method of recording might explain differences between studies (Fetrow et al., 2006).

Although the shape of the curve was altered with uncomplicated or complicated MD, a slower increase to a lower peak seemed to be compensated for by better persistency, so that the change in total production (M305) was less marked than the change in the distribution of production within the lactation. It has been reported since the early 1990s that metabolic problems negatively affect fertility in dairy cows (Staples et al., 1990). As cows are less likely to conceive when they contract one or more MD (Leroy et al., 2008), the absence of a pregnancy may be related to the greater persistency in both MD and MD+ cows (Svennersten-Sjaunja and Olsson, 2005).

In most studies, a positive association between TWIN and milk production in the lactation carrying twins has been described, as comprehensively discussed by Fricke (2001). The results in the present study showing decreased M60, MPEAK, and M305 in the lactation subsequent to complicated TWIN compared with $\mathrm{H}$ cows confirm the conclusions made by Nielen et al. (1989) and Mostafa (2009). Neither of those studies, however, accounted for all other diseases, which might explain the lack of effect in our study for the uncomplicated 
Table 4. The effect of twinning on MilkBot parameter values and calculated metrics for fitted individual lactation curves ${ }^{1}$

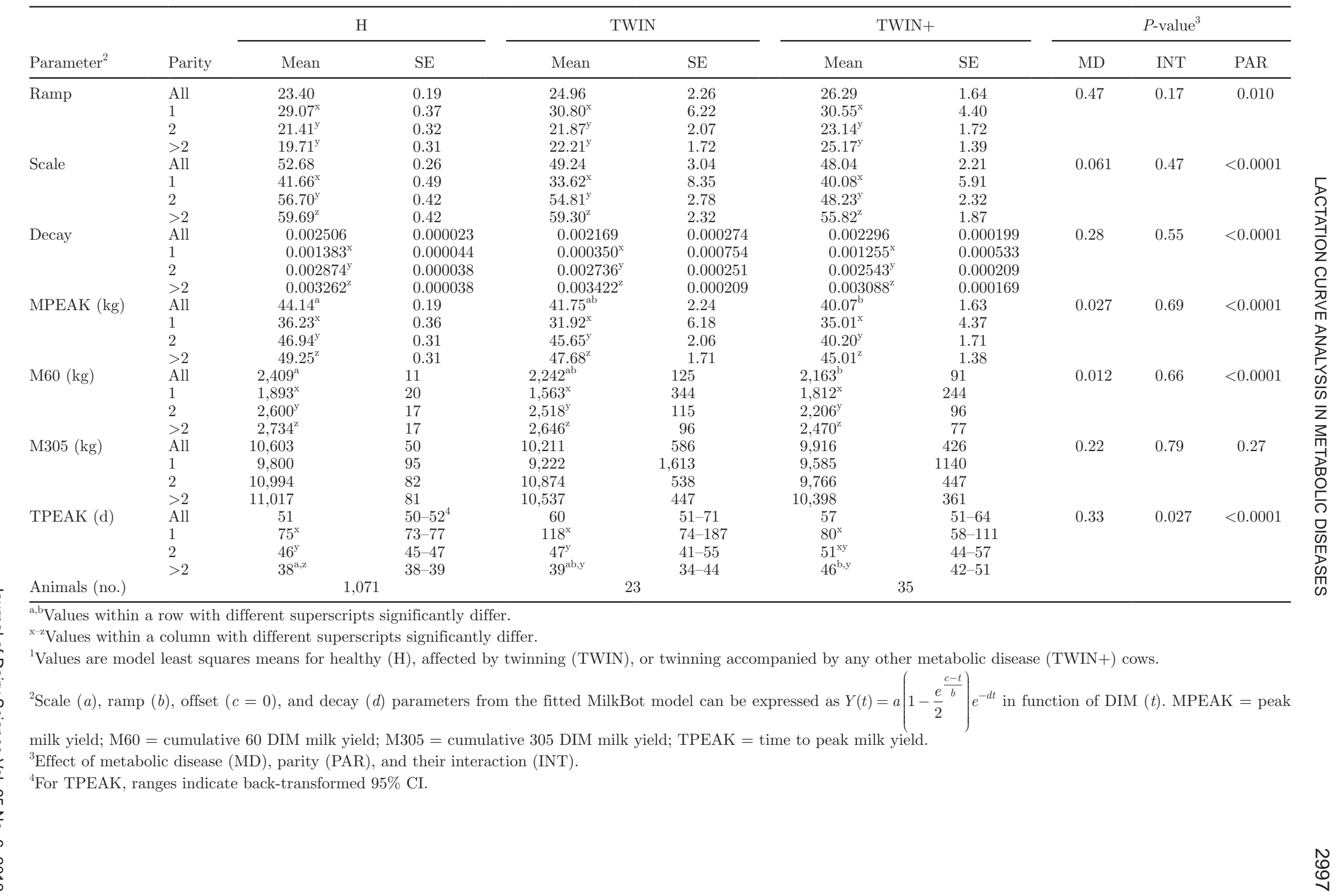


Table 5. The effect of milk fever on MilkBot parameter values and calculated metrics for fitted individual lactation curves ${ }^{1}$

\begin{tabular}{|c|c|c|c|c|c|c|c|c|c|c|}
\hline \multirow[b]{2}{*}{ Parameter $^{2}$} & \multirow[b]{2}{*}{ Parity } & \multicolumn{2}{|c|}{$\mathrm{H}$} & \multicolumn{2}{|c|}{ MF } & \multicolumn{2}{|c|}{$\mathrm{MF}+$} & \multicolumn{3}{|c|}{$P$-value ${ }^{3}$} \\
\hline & & Mean & $\mathrm{SE}$ & Mean & $\mathrm{SE}$ & Mean & $\mathrm{SE}$ & MD & INT & PAR \\
\hline \multirow[t]{4}{*}{ Ramp } & All & $20.55^{\mathrm{a}}$ & 0.37 & $22.20^{\mathrm{a}}$ & 1.03 & $27.69^{\mathrm{b}}$ & 1.52 & $<0.0001$ & 0.40 & 0.071 \\
\hline & $2-3$ & 20.56 & 0.29 & 22.06 & 1.90 & 25.68 & 1.98 & & & \\
\hline & 4 & 20.76 & 0.76 & 23.80 & 1.64 & 32.13 & 2.91 & & & \\
\hline & $>4$ & 20.31 & 0.77 & 20.74 & 1.78 & 25.27 & 2.91 & & & \\
\hline \multirow[t]{4}{*}{ Scale } & All & $58.88^{\mathrm{a}}$ & 0.47 & $61.82^{\mathrm{a}}$ & 1.30 & $53.43^{\mathrm{b}}$ & 1.93 & 0.0015 & 0.080 & 0.017 \\
\hline & $2-3$ & $57.87^{\mathrm{xy}}$ & 0.37 & $65.47^{\mathrm{xy}}$ & 2.41 & $52.11^{\mathrm{xy}}$ & 2.50 & & & \\
\hline & 4 & $60.99^{x}$ & 0.97 & $64.51^{\mathrm{x}}$ & 2.07 & $56.78^{\mathrm{x}}$ & 3.69 & & & \\
\hline & $>4$ & $57.79^{\mathrm{y}}$ & 0.98 & $55.49^{\mathrm{y}}$ & 2.26 & $51.40^{y}$ & 3.69 & & & \\
\hline \multirow[t]{4}{*}{ Decay } & All & $0.003247^{\mathrm{a}}$ & 0.000043 & $0.003298^{\mathrm{a}}$ & 0.000118 & $0.002548^{\mathrm{b}}$ & 0.000176 & 0.0005 & 0.13 & 0.31 \\
\hline & $2-3$ & 0.002982 & 0.000033 & 0.003304 & 0.000220 & 0.002763 & 0.000228 & & & \\
\hline & 4 & 0.003440 & 0.000088 & 0.003405 & 0.000189 & 0.002702 & 0.000336 & & & \\
\hline & $>4$ & 0.003320 & 0.000089 & 0.003185 & 0.000206 & 0.002178 & 0.000336 & & & \\
\hline \multirow[t]{4}{*}{ MPEAK (kg) } & All & $48.32^{\mathrm{a}}$ & 0.35 & $50.09^{\mathrm{a}}$ & 0.95 & $43.41^{\mathrm{b}}$ & 1.41 & 0.0005 & 0.087 & 0.11 \\
\hline & $2-3$ & 47.99 & 0.27 & 53.28 & 1.77 & 42.40 & 1.84 & & & \\
\hline & 4 & 49.64 & 0.71 & 51.38 & 1.52 & 44.35 & 2.70 & & & \\
\hline & $>4$ & 47.34 & 0.72 & 45.61 & 1.65 & 43.49 & 2.70 & & & \\
\hline \multirow{4}{*}{ M60 (kg) } & All & $2,682^{\mathrm{a}}$ & 20 & $2,776^{\mathrm{a}}$ & 54 & $2,360^{\mathrm{b}}$ & 80 & $<0.0001$ & 0.10 & 0.11 \\
\hline & $2-3$ & 2,660 & 15 & 2,948 & 100 & 2,319 & 104 & & & \\
\hline & 4 & 2,754 & 40 & 2,853 & 86 & 2,403 & 152 & & & \\
\hline & $>4$ & 2,631 & 40 & 2,527 & 93 & 2,357 & 152 & & & \\
\hline \multirow{4}{*}{ M305 (kg) } & All & 10,869 & 88 & 11,259 & 240 & 10,624 & 356 & 0.23 & 0.19 & 0.25 \\
\hline & $2-3$ & 11,071 & 67 & 11,971 & 446 & 10,166 & 462 & & & \\
\hline & 4 & 10,979 & 179 & 11,518 & 382 & 10,877 & 681 & & & \\
\hline & $>4$ & 10,557 & 181 & 10,288 & 417 & 10,829 & 681 & & & \\
\hline \multirow{4}{*}{ TPEAK (d) } & All & $40^{\mathrm{a}}$ & $39-41^{4}$ & $42^{\mathrm{a}}$ & $39-45$ & $54^{\mathrm{b}}$ & $49-60$ & $<0.0001$ & 0.22 & 0.73 \\
\hline & $2-3$ & 43 & $42-44$ & 41 & $36-47$ & 51 & $44-59$ & & & \\
\hline & 4 & 39 & $37-41$ & 43 & $38-48$ & 59 & $48-72$ & & & \\
\hline & $>4$ & 39 & $37-41$ & 41 & $36-47$ & 53 & $43-66$ & & & \\
\hline Animals (no.) & & 78 & & 49 & & 25 & & & & \\
\hline
\end{tabular}

$\overline{\mathrm{a}, \mathrm{b}}$ Values within a row with different superscripts significantly differ.

${ }^{\mathrm{x}, \mathrm{y}}$ Values within a column with different superscripts significantly differ.

${ }^{1}$ Values are model least squares means for healthy $(\mathrm{H})$, affected by milk fever only (MF), or milk fever accompanied by any other metabolic disease (MF + ) cows.

${ }^{2}$ Scale $(a), \operatorname{ramp}(b)$, offset $(c=0)$, and decay $(d)$ parameters from the fitted MilkBot model can be expressed as $Y(t)=a\left(1-\frac{e^{\frac{c-t}{b}}}{2}\right) e^{-d t}$ in function of DIM $(t)$. MPEAK $=$ peak milk yield; M60 = cumulative 60 DIM milk yield; M305 = cumulative 305 DIM milk yield; TPEAK = time to peak milk yield.

${ }^{3}$ Effect of metabolic disease (MD), parity (PAR), and their interaction (INT).

${ }^{4}$ For TPEAK, ranges indicate back-transformed $95 \%$ CI. 
Table 6. The effect of retained placenta on MilkBot parameter values and calculated metrics for fitted individual lactation curves ${ }^{1}$

\begin{tabular}{|c|c|c|c|c|c|c|c|c|c|c|}
\hline \multirow[b]{2}{*}{ Parameter $^{2}$} & \multirow[b]{2}{*}{ Parity } & \multicolumn{2}{|c|}{$\mathrm{H}$} & \multicolumn{2}{|c|}{$\mathrm{RP}$} & \multicolumn{2}{|c|}{$\mathrm{RP}+$} & \multicolumn{3}{|c|}{$P$-value ${ }^{3}$} \\
\hline & & Mean & $\mathrm{SE}$ & Mean & $\mathrm{SE}$ & Mean & $\mathrm{SE}$ & $\mathrm{MD}$ & INT & PAR \\
\hline \multirow[t]{4}{*}{ Ramp } & All & 23.40 & 0.19 & 23.94 & 1.80 & 24.91 & 1.01 & 0.33 & 0.77 & $<0.0001$ \\
\hline & 1 & $29.07^{\mathrm{x}}$ & 0.36 & $28.75^{x}$ & 2.48 & $30.40^{\mathrm{x}}$ & 1.92 & & & \\
\hline & 2 & $21.41^{y}$ & 0.31 & $20.45^{y}$ & 4.30 & $22.11^{\mathrm{y}}$ & 1.75 & & & \\
\hline & $>2$ & $19.71^{\mathrm{y}}$ & 0.31 & $22.63^{\mathrm{y}}$ & 2.15 & $22.23^{\mathrm{y}}$ & 1.57 & & & \\
\hline \multirow[t]{4}{*}{ Scale } & All & $52.68^{\mathrm{a}}$ & 0.25 & $54.24^{\mathrm{ab}}$ & 2.45 & $48.26^{\mathrm{b}}$ & 1.38 & 0.0054 & 0.020 & $<0.0001$ \\
\hline & 1 & $41.66^{\mathrm{x}}$ & 0.49 & 46.65 & 3.37 & $41.88^{\mathrm{x}}$ & 2.61 & & & \\
\hline & 2 & $56.70^{\mathrm{a}, \mathrm{y}}$ & 0.42 & $61.80^{\mathrm{ab}}$ & 5.83 & $48.46^{\mathrm{b}, \mathrm{xy}}$ & 2.38 & & & \\
\hline & $>2$ & $59.69^{\mathrm{z}}$ & 0.42 & 54.28 & 2.92 & $54.43^{\mathrm{y}}$ & 2.13 & & & \\
\hline \multirow[t]{4}{*}{ Decay } & All & $0.002506^{\mathrm{a}}$ & 0.000023 & $0.002138^{\mathrm{ab}}$ & 0.000223 & $0.002132^{\mathrm{b}}$ & 0.000125 & 0.0039 & 0.35 & $<0.0001$ \\
\hline & 1 & $0.001383^{x}$ & 0.000044 & $0.001165^{\mathrm{x}}$ & 0.000306 & $0.001333^{\mathrm{x}}$ & 0.000237 & & & \\
\hline & 2 & $0.002874^{\mathrm{y}}$ & 0.000038 & $0.002630^{\mathrm{y}}$ & 0.000531 & $0.002240^{\mathrm{y}}$ & 0.000217 & & & \\
\hline & $>2$ & $0.003262^{y}$ & 0.000038 & $0.002620^{y}$ & 0.000265 & $0.002824^{y}$ & 0.000194 & & & \\
\hline \multirow[t]{4}{*}{ MPEAK (kg) } & All & $44.14^{\mathrm{a}}$ & 0.19 & $46.21^{\mathrm{a}}$ & 1.82 & $41.00^{\mathrm{b}}$ & 1.03 & 0.0055 & 0.0081 & $<0.0001$ \\
\hline & 1 & $36.23^{\mathrm{x}}$ & 0.36 & 41.22 & 2.51 & $36.71^{\mathrm{x}}$ & 1.95 & & & \\
\hline & 2 & $46.94^{\mathrm{a}, \mathrm{y}}$ & 0.31 & $52.07^{\mathrm{ab}}$ & 4.35 & $41.20^{\mathrm{b}, \mathrm{xy}}$ & 1.78 & & & \\
\hline & $>2$ & $49.25^{\mathrm{z}}$ & 0.31 & 45.34 & 2.17 & $45.10^{\mathrm{y}}$ & 1.59 & & & \\
\hline \multirow[t]{4}{*}{ M60 (kg) } & All & $2,409^{\mathrm{a}}$ & 11 & $2,505^{\mathrm{a}}$ & 102 & $2,207^{\mathrm{b}}$ & 57 & 0.0015 & 0.0072 & $<0.0001$ \\
\hline & 1 & $1,893^{\mathrm{x}}$ & 20 & 2,140 & 140 & $1,894^{\mathrm{x}}$ & 108 & & & \\
\hline & 2 & $2,600^{\mathrm{a}, \mathrm{y}}$ & 17 & $2,884^{\mathrm{ab}}$ & 242 & $2,253^{\mathrm{b}, \mathrm{xy}}$ & 99 & & & \\
\hline & $>2$ & $2,734^{z}$ & 17 & 2,490 & 121 & $2,474^{\mathrm{y}}$ & 88 & & & \\
\hline \multirow[t]{4}{*}{ M305 (kg) } & All & 10,603 & 50 & 11,553 & 478 & 10,265 & 268 & 0.063 & 0.18 & 0.22 \\
\hline & 1 & 9,800 & 95 & 11,342 & 657 & 10,027 & 509 & & & \\
\hline & 2 & 10,994 & 82 & 12,455 & 1138 & 10,220 & 465 & & & \\
\hline & $>2$ & 11,017 & 81 & 10,862 & 569 & 10,548 & 416 & & & \\
\hline \multirow[t]{4}{*}{ TPEAK (d) } & All & $51^{\mathrm{a}}$ & $50-52^{4}$ & $55^{\mathrm{ab}}$ & $48-63$ & $58^{\mathrm{b}}$ & $54-62$ & 0.0028 & 0.44 & $<0.0001$ \\
\hline & 1 & $75^{\mathrm{x}}$ & $73-77$ & $78^{\mathrm{x}}$ & 65-94 & $80^{\mathrm{x}}$ & 69-92 & & & \\
\hline & 2 & $46^{\mathrm{y}}$ & $45-47$ & $46^{\mathrm{y}}$ & $33-63$ & $53^{\mathrm{y}}$ & $47-61$ & & & \\
\hline & $>2$ & $38^{\mathrm{y}}$ & $38-39$ & $47^{\mathrm{y}}$ & $40-55$ & $46^{\mathrm{y}}$ & $40-51$ & & & \\
\hline Animals (no.) & \multicolumn{3}{|c|}{1,071} & \multicolumn{4}{|c|}{37} & & & \\
\hline \multicolumn{11}{|c|}{$\overline{\mathrm{a}, \mathrm{b}}$ Values within a row with different superscripts significantly differ. } \\
\hline \multirow{2}{*}{\multicolumn{11}{|c|}{$\begin{array}{l}{ }^{\mathrm{x}-\mathrm{z}} \text { Values within a column with different superscripts significantly differ. } \\
{ }^{1} \text { alues are model least squares means for healthy }(\mathrm{H}) \text {, affected by retained placenta only }(\mathrm{RP}) \text {, or retained placenta accompanied by any other metabolic disease }(\mathrm{RP}+) \text { cows. }\end{array}$}} \\
\hline & & & & & & & & & & \\
\hline \multicolumn{11}{|c|}{${ }^{2}$ Scale $(a)$, ramp $(b)$, offset $(c=0)$, and decay $(d)$ parameters from the fitted MilkBot model can be expressed as $Y(t)=a\left|1-\frac{e^{\bar{b}}}{2}\right| e^{-d t}$ in function of DIM $(t)$. MPEAK $=$ peak } \\
\hline \multicolumn{11}{|c|}{ milk yield; M60 = cumulative 60 DIM milk yield; M305 = cumulative 305 DIM milk yield; TPEAK = time to peak milk yield. } \\
\hline \multicolumn{11}{|c|}{${ }^{4}$ For TPEAK, ranges indicate back-transformed $95 \%$ CI. } \\
\hline
\end{tabular}


Table 7. The effect of metritis on MilkBot parameter values and calculated metrics for fitted individual lactation curves ${ }^{1}$

\begin{tabular}{|c|c|c|c|c|c|c|c|c|c|c|}
\hline \multirow[b]{2}{*}{ Parameter $^{2}$} & \multirow[b]{2}{*}{ Parity } & \multicolumn{2}{|c|}{$\mathrm{H}$} & \multicolumn{2}{|c|}{ METR } & \multicolumn{2}{|c|}{ METR+ } & \multicolumn{3}{|c|}{$P$-value ${ }^{3}$} \\
\hline & & Mean & $\mathrm{SE}$ & Mean & $\mathrm{SE}$ & Mean & $\mathrm{SE}$ & MD & INT & PAR \\
\hline \multirow[t]{4}{*}{ Ramp } & All & $23.40^{\mathrm{a}}$ & 0.18 & $25.28^{\mathrm{b}}$ & 0.62 & $27.15^{\mathrm{b}}$ & 0.64 & $<0.0001$ & $<0.0001$ & $<0.0001$ \\
\hline & 1 & $29.07^{\mathrm{x}}$ & 0.35 & $29.32^{\mathrm{x}}$ & 0.59 & $30.36^{\mathrm{x}}$ & $\begin{array}{l}.07 \\
1.02\end{array}$ & & & \\
\hline & 2 & $21.41^{\mathrm{y}}$ & 0.30 & $22.34^{\mathrm{y}}$ & 1.09 & $22.75^{\mathrm{y}}$ & 1.22 & & & \\
\hline & $>2$ & $19.71^{\mathrm{a}, \mathrm{z}}$ & 0.30 & $24.17^{\mathrm{b}, \mathrm{y}}$ & 1.37 & $28.35^{\mathrm{b}, \mathrm{x}}$ & 1.07 & & & \\
\hline \multirow[t]{4}{*}{ Scale } & All & $52.68^{\mathrm{a}}$ & 0.25 & $50.84^{\mathrm{ab}}$ & 0.84 & $48.26^{\mathrm{b}}$ & 0.87 & $<0.0001$ & 0.0096 & $<0.0001$ \\
\hline & 1 & $41.66^{\mathrm{x}}$ & 0.48 & $41.66^{\mathrm{x}}$ & 0.81 & $41.20^{\mathrm{x}}$ & 1.40 & & & \\
\hline & 2 & $56.70^{\mathrm{a}, \mathrm{y}}$ & 0.41 & $52.92^{\text {ab,y }}$ & 1.49 & $50.22^{\mathrm{b}, \mathrm{y}}$ & 1.67 & & & \\
\hline & $>2$ & $59.69^{\mathrm{a}, \mathrm{z}}$ & 0.41 & $57.94^{\mathrm{ab}, \mathrm{y}}$ & 1.87 & $53.35^{\mathrm{b}, \mathrm{y}}$ & 1.47 & & & \\
\hline \multirow[t]{4}{*}{ Decay } & All & $0.002506^{\mathrm{a}}$ & 0.000023 & $0.002310^{\mathrm{b}}$ & 0.000077 & $0.002195^{\mathrm{b}}$ & 0.000080 & $<0.0001$ & 0.21 & $<0.0001$ \\
\hline & 1 & $0.001383^{\mathrm{x}}$ & 0.000044 & $0.001402^{\mathrm{x}}$ & 0.000074 & $0.001166^{\mathrm{x}}$ & 0.000128 & & & \\
\hline & 2 & $0.002874^{\mathrm{y}}$ & 0.000038 & $0.002594^{\mathrm{y}}$ & 0.000136 & $0.002572^{y}$ & 0.000152 & & & \\
\hline & $>2$ & $0.003262^{\mathrm{z}}$ & 0.000037 & $0.002935^{\mathrm{z}}$ & 0.000171 & $0.002846^{\mathrm{z}}$ & 0.000134 & & & \\
\hline \multirow[t]{4}{*}{ MPEAK (kg) } & All & $44.14^{\mathrm{a}}$ & 0.19 & $42.56^{\mathrm{b}}$ & 0.63 & $40.36^{\mathrm{c}}$ & 0.66 & $<0.0001$ & 0.0002 & $<0.0001$ \\
\hline & 1 & $36.23^{\mathrm{x}}$ & 0.36 & $36.19^{\mathrm{x}}$ & 0.61 & $36.47^{\mathrm{x}}$ & 1.05 & & & \\
\hline & 2 & $46.94^{\mathrm{a}, \mathrm{y}}$ & 0.31 & $44.13^{\mathrm{ab}, \mathrm{y}}$ & 1.12 & $41.83^{\mathrm{b}, \mathrm{y}}$ & 1.25 & & & \\
\hline & $>2$ & $49.25^{\mathrm{a}, \mathrm{z}}$ & 0.31 & $47.36^{\mathrm{ab}, \mathrm{y}}$ & 1.41 & $42.79^{\mathrm{b}, y}$ & 1.10 & & & \\
\hline \multirow{4}{*}{ M60 (kg) } & All & $2,409^{\mathrm{a}}$ & 11 & $2,307^{\mathrm{b}}$ & 35 & $2,168^{\mathrm{c}}$ & 36 & $<0.0001$ & $<0.0001$ & $<0.0001$ \\
\hline & 1 & $1,893^{\mathrm{x}}$ & 20 & $1,890^{\mathrm{x}}$ & 34 & $1,873^{x}$ & 58 & & & \\
\hline & 2 & $2,600^{\mathrm{a}, \mathrm{y}}$ & 17 & $2,429^{\mathrm{ab}, \mathrm{y}}$ & 62 & $2,298^{\mathrm{b}, \mathrm{y}}$ & 69 & & & \\
\hline & $>2$ & $2,734^{\mathrm{a}, \mathrm{z}}$ & 17 & $2,603^{\mathrm{ab}, \mathrm{y}}$ & 78 & $2,332^{\mathrm{b}, \mathrm{y}}$ & 61 & & & \\
\hline \multirow[t]{4}{*}{ M305 (kg) } & All & $10,603^{\mathrm{a}}$ & 50 & $10,479^{\mathrm{ab}}$ & 166 & $10,114^{\mathrm{b}}$ & 172 & 0.021 & 0.044 & $<0.0001$ \\
\hline & 1 & $9,800^{\mathrm{x}}$ & 95 & $9,774^{\mathrm{x}}$ & 160 & 10,046 & 276 & & & \\
\hline & 2 & $10,994^{\mathrm{y}}$ & 81 & $10,608^{\mathrm{xy}}$ & 293 & 10,093 & 328 & & & \\
\hline & $>2$ & $11.017^{\mathrm{y}}$ & 81 & $11.054^{\mathrm{y}}$ & 369 & 10,202 & 289 & & & \\
\hline \multirow[t]{4}{*}{ TPEAK (d) } & All & $51^{\mathrm{a}}$ & $50-52^{4}$ & $55^{\mathrm{b}}$ & $52-58$ & $60^{\mathrm{c}}$ & $58-63$ & $<0.0001$ & 0.0012 & $<0.0001$ \\
\hline & 1 & $75^{\mathrm{x}}$ & $73-77$ & $75^{\mathrm{x}}$ & $72-79$ & $84^{\mathrm{x}}$ & $78-91$ & & & \\
\hline & 2 & $46^{y}$ & $45-47$ & $49^{y}$ & $45-54$ & $51^{\mathrm{y}}$ & $46-55$ & & & \\
\hline & $>2$ & $38^{\mathrm{a}, \mathrm{z}}$ & 38-39 & $45^{\mathrm{ab}, y}$ & $40-50$ & $52^{\mathrm{b}, \mathrm{y}}$ & $48-56$ & & & \\
\hline Animals (no.) & \multicolumn{3}{|c|}{1,071} & 150 & & \multicolumn{2}{|l|}{89} & & & \\
\hline
\end{tabular}

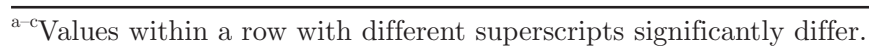

${ }^{\mathrm{x}-\mathrm{z}}$ Values within a column with different superscripts significantly differ.

${ }^{1}$ Values are model least squares means for healthy $(\mathrm{H})$, affected by a metritis (METR), or a metritis accompanied by any other metabolic disease (METR + ) cows.

${ }^{2}$ Scale $(a), \operatorname{ramp}(b)$, offset $(c=0)$, and decay $(d)$ parameters from the fitted MilkBot model can be expressed as $Y(t)=a\left(1-\frac{e^{\frac{c-t}{b}}}{2}\right) e^{-d t}$ in function of DIM $(t)$. MPEAK $=$ peak milk yield; M60 = cumulative 60 DIM milk yield; M305 = cumulative 305 DIM milk yield; TPEAK = time to peak milk yield.

${ }^{3}$ Effect of metabolic disease (MD), parity (PAR), and their interaction (INT)

${ }^{4}$ For TPEAK, ranges indicate back-transformed $95 \%$ CI. 
Table 9. The effect of abomasal displacement on MilkBot parameter values and calculated metrics for fitted individual lactation curves

\begin{tabular}{|c|c|c|c|c|c|c|c|c|c|c|}
\hline \multirow[b]{2}{*}{ Parameter $^{2}$} & \multirow[b]{2}{*}{ Parity } & \multicolumn{2}{|c|}{$\mathrm{H}$} & \multicolumn{2}{|c|}{ DA } & \multicolumn{2}{|c|}{$\mathrm{DA}+$} & \multicolumn{3}{|c|}{$P$-value ${ }^{3}$} \\
\hline & & Mean & $\mathrm{SE}$ & Mean & $\mathrm{SE}$ & Mean & $\mathrm{SE}$ & MD & INT & PAR \\
\hline \multirow[t]{4}{*}{ Ramp } & All & $21.42^{\mathrm{a}}$ & 0.24 & $28.28^{\mathrm{ab}}$ & 2.97 & $32.17^{\mathrm{b}}$ & 1.64 & $<0.0001$ & 0.0008 & 0.94 \\
\hline & $1-2$ & $24.66^{x}$ & 0.26 & 28.45 & 4.76 & 27.39 & 1.87 & & & \\
\hline & 3 & $19.06^{\mathrm{a}, \mathrm{y}}$ & 0.45 & $24.20^{\mathrm{ab}}$ & 6.74 & $39.00^{\mathrm{b}}$ & 3.89 & & & \\
\hline & $>3$ & $20.54^{\mathrm{a}, \mathrm{y}}$ & 0.51 & $32.20^{\mathrm{b}}$ & 3.37 & $30.11^{\mathrm{b}}$ & 2.38 & & & \\
\hline \multirow[t]{4}{*}{ Scale } & All & $56.54^{\mathrm{a}}$ & 0.36 & $50.80^{\mathrm{ab}}$ & 4.45 & $50.96^{\mathrm{b}}$ & 2.46 & 0.037 & 0.40 & 0.0026 \\
\hline & $1-2$ & $50.31^{x}$ & 0.39 & $48.43^{\mathrm{x}}$ & 7.13 & $44.99^{\mathrm{x}}$ & 2.80 & & & \\
\hline & 3 & $59.91^{\mathrm{y}}$ & 0.68 & $45.32^{\mathrm{y}}$ & 10.08 & $48.92^{\mathrm{y}}$ & 5.82 & & & \\
\hline & $>3$ & $59.40^{y}$ & 0.77 & $58.65^{y}$ & 5.04 & $58.98^{\mathrm{z}}$ & 3.56 & & & \\
\hline \multirow[t]{4}{*}{ Decay } & All & $0.002931^{\mathrm{a}}$ & 0.000034 & $0.002113^{\mathrm{ab}}$ & 0.000417 & $0.002191^{\mathrm{b}}$ & 0.000231 & 0.0011 & 0.81 & $<0.0001$ \\
\hline & $1-2$ & $0.002241^{\mathrm{x}}$ & 0.000036 & $0.001045^{\mathrm{x}}$ & 0.000669 & $0.001625^{\mathrm{x}}$ & 0.000262 & & & \\
\hline & 3 & $0.003170^{\mathrm{xy}}$ & 0.000063 & $0.002200^{\mathrm{xy}}$ & 0.000946 & $0.002310^{\mathrm{xy}}$ & 0.000546 & & & \\
\hline & $>3$ & $0.003381^{y}$ & 0.000072 & $0.003095^{\mathrm{y}}$ & 0.000473 & $0.002636^{\mathrm{y}}$ & 0.000335 & & & \\
\hline \multirow[t]{4}{*}{ MPEAK $(\mathrm{kg})$} & All & $46.91^{\mathrm{a}}$ & 0.27 & $42.36^{\mathrm{ab}}$ & 3.25 & $41.40^{\mathrm{b}}$ & 1.80 & 0.0041 & 0.19 & 0.051 \\
\hline & $1-2$ & 42.39 & 0.28 & 43.45 & 5.21 & 38.95 & 2.04 & & & \\
\hline & 3 & 49.83 & 0.49 & 38.09 & 7.37 & 38.19 & 4.25 & & & \\
\hline & $>3$ & 48.50 & 0.56 & 45.54 & 3.68 & 47.05 & 2.61 & & & \\
\hline \multirow{4}{*}{ M60 (kg) } & All & $2,586^{\mathrm{a}}$ & 16 & $2,264^{\mathrm{ab}}$ & 193 & $2,211^{\mathrm{b}}$ & 107 & 0.0007 & 0.24 & 0.027 \\
\hline & $1-2$ & $2,300^{\mathrm{x}}$ & 17 & $2,253^{\mathrm{x}}$ & 309 & $2,056^{\mathrm{x}}$ & 121 & & & \\
\hline & 3 & $2.766^{\mathrm{xy}}$ & 29 & $2,065^{\mathrm{xy}}$ & 437 & $2,031^{\mathrm{xy}}$ & 252 & & & \\
\hline & $>3$ & $2,693^{y}$ & 33 & $2,474^{\mathrm{y}}$ & 218 & $2,547^{\mathrm{y}}$ & 154 & & & \\
\hline \multirow{4}{*}{ M305 (kg) } & All & 10,821 & 60 & 10,779 & 731 & 10,526 & 404 & 0.77 & 0.16 & 0.50 \\
\hline & $1-2$ & 10,487 & 64 & 11,975 & 1,172 & 10,209 & 460 & & & \\
\hline & 3 & 11,207 & 111 & 9,549 & 1,657 & 9,827 & 957 & & & \\
\hline & $>3$ & 10,771 & 126 & 10,813 & 829 & 11,542 & 586 & & & \\
\hline \multirow[t]{4}{*}{ TPEAK (d) } & All & $44^{\mathrm{a}}$ & $43-45^{4}$ & $63^{\mathrm{b}}$ & $48-82$ & $66^{\mathrm{b}}$ & $57-77$ & $<0.0001$ & 0.36 & 0.0049 \\
\hline & $1-2$ & $56^{\mathrm{x}}$ & $55-58$ & $80^{\mathrm{x}}$ & $52-122$ & $71^{\mathrm{x}}$ & $60-84$ & & & 0.0078 \\
\hline & 3 & $38^{x y}$ & $37-40$ & $55^{\mathrm{xy}}$ & $30-101$ & $70^{x y}$ & 50-99 & & & \\
\hline & $>3$ & $39^{y}$ & $37-41$ & $56^{\mathrm{y}}$ & $41-75$ & $58^{\mathrm{y}}$ & $47-72$ & & & \\
\hline Animals (no.) & \multicolumn{3}{|c|}{1,071} & 7 & & \multicolumn{2}{|l|}{24} & & & \\
\hline
\end{tabular}

${ }^{\mathrm{a}, \mathrm{b}}$ Values within a row with different superscripts significantly differ.

${ }^{\mathrm{x}, \mathrm{y}}$ Values within a column with different superscripts significantly differ.

${ }^{1}$ Values are model least squares means for healthy $(\mathrm{H})$, affected by an abomasal displacement (DA), or an abomasal displacement accompanied by any other metabolic disease $(\mathrm{DA}+)$ cows.

${ }^{2}$ Scale $(a)$, ramp $(b)$, offset $(c=0)$, and decay $(d)$ parameters from the fitted MilkBot model can be expressed as $Y(t)=a\left(1-\frac{e^{\frac{c-t}{b}}}{2}\right) e^{-d t}$ in function of DIM $(t)$. MPEAK $=$ peak milk yield; M60 = cumulative 60 DIM milk yield; M305 = cumulative 305 DIM milk yield; TPEAK = time to peak milk yield.

${ }^{3}$ Effect of metabolic disease (MD), parity (PAR), and their interaction (INT).

${ }^{4}$ For TPEAK, ranges indicate back-transformed $95 \%$ CI. 
Table 10. The effect of mastitis within 30 DIM on MilkBot parameter values and calculated metrics for fitted individual lactation curves ${ }^{1}$

\begin{tabular}{|c|c|c|c|c|c|c|c|c|c|c|}
\hline \multirow[b]{2}{*}{ Parameter $^{2}$} & \multirow[b]{2}{*}{ Parity } & \multicolumn{2}{|c|}{$\mathrm{H}$} & \multicolumn{2}{|c|}{ MAST } & \multicolumn{2}{|c|}{ MAST +} & \multicolumn{3}{|c|}{$P$-value ${ }^{3}$} \\
\hline & & Mean & $\mathrm{SE}$ & Mean & $\mathrm{SE}$ & Mean & $\mathrm{SE}$ & MD & INT & PAR \\
\hline \multirow[t]{4}{*}{ Ramp } & All & 23.40 & 0.19 & 24.35 & 0.98 & 24.69 & 1.26 & 0.39 & 0.89 & $<0.0001$ \\
\hline & 1 & $29.07^{\mathrm{x}}$ & 0.36 & $30.04^{x}$ & 2.05 & $29.39^{\mathrm{x}}$ & 2.18 & & & \\
\hline & 2 & $21.41^{\mathrm{y}}$ & 0.31 & $21.67^{\mathrm{y}}$ & 1.59 & $22.32^{\mathrm{y}}$ & 2.52 & & & \\
\hline & $>2$ & $19.71^{\mathrm{y}}$ & 0.31 & $21.33^{\mathrm{y}}$ & 1.34 & $22.38^{\mathrm{y}}$ & 1.78 & & & \\
\hline \multirow[t]{4}{*}{ Scale } & All & $52.68^{\mathrm{a}}$ & 0.25 & $53.10^{\mathrm{a}}$ & 1.30 & $47.65^{\mathrm{b}}$ & 1.68 & 0.012 & 0.461 & $<0.0001$ \\
\hline & 1 & $41.66^{\mathrm{x}}$ & 0.48 & $43.74^{\mathrm{x}}$ & 2.74 & $40.17^{\mathrm{x}}$ & 2.90 & & & \\
\hline & 2 & $56.70^{\mathrm{y}}$ & 0.42 & $55.87^{\mathrm{y}}$ & 2.12 & $51.16^{\mathrm{y}}$ & 3.35 & & & \\
\hline & $>2$ & $59.69^{\mathrm{y}}$ & 0.41 & $59.68^{\mathrm{y}}$ & 1.79 & $51.62^{\mathrm{y}}$ & 2.37 & & & \\
\hline \multirow[t]{4}{*}{ Decay } & All & $0.002506^{\mathrm{a}}$ & 0.000023 & $0.002366^{\mathrm{ab}}$ & 0.000119 & $0.002131^{\mathrm{b}}$ & 0.000154 & 0.031 & 0.52 & $<0.0001$ \\
\hline & 1 & $0.001383^{\mathrm{x}}$ & 0.000045 & $0.001363^{\mathrm{x}}$ & 0.000251 & $0.001340^{\mathrm{x}}$ & 0.000267 & & & \\
\hline & 2 & $0.002874^{\mathrm{y}}$ & 0.000038 & $0.002716^{\mathrm{y}}$ & 0.000195 & $0.002417^{\mathrm{y}}$ & 0.000308 & & & \\
\hline & $>2$ & $0.003262^{y}$ & 0.000038 & $0.003020^{y}$ & 0.000165 & $0.002638^{\mathrm{y}}$ & 0.000218 & & & \\
\hline \multirow[t]{4}{*}{ MPEAK (kg) } & All & $44.14^{\mathrm{a}}$ & 0.19 & $44.78^{\mathrm{a}}$ & 0.97 & $40.52^{\mathrm{b}}$ & 1.25 & 0.013 & 0.45 & $<0.0001$ \\
\hline & 1 & $36.23^{x}$ & 0.36 & $38.00^{\mathrm{x}}$ & 2.04 & $35.25^{\mathrm{x}}$ & 2.17 & & & \\
\hline & 2 & $46.94^{\mathrm{y}}$ & 0.31 & $46.64^{y}$ & 1.58 & $43.08^{\mathrm{y}}$ & 2.50 & & & \\
\hline & $>2$ & $49.25^{\mathrm{y}}$ & 0.31 & $49.69^{\mathrm{y}}$ & 1.34 & $43.24^{\mathrm{y}}$ & 1.77 & & & \\
\hline \multirow[t]{4}{*}{ M60 (kg) } & All & $2,409^{\mathrm{a}}$ & 11 & $2,423^{\mathrm{a}}$ & 54 & $2,191^{\mathrm{b}}$ & 70 & 0.0081 & 0.41 & $<0.0001$ \\
\hline & 1 & $1,893^{\mathrm{x}}$ & 20 & $1,974^{\mathrm{x}}$ & 114 & $1,829^{\mathrm{x}}$ & 121 & & & \\
\hline & 2 & $2,600^{y}$ & 17 & $2,570^{\mathrm{y}}$ & 88 & $2,367^{\mathrm{y}}$ & 139 & & & \\
\hline & $>2$ & $2,734^{\mathrm{y}}$ & 17 & $2,726^{\mathrm{y}}$ & 74 & $2,378^{\mathrm{y}}$ & 98 & & & \\
\hline \multirow[t]{4}{*}{ M305 (kg) } & All & 10,603 & 50 & 10,941 & 256 & 10,179 & 331 & 0.18 & 0.95 & 0.0042 \\
\hline & 1 & $9,800^{\mathrm{x}}$ & 96 & $10,281^{\mathrm{x}}$ & 540 & $9,618^{\mathrm{x}}$ & 573 & & & \\
\hline & 2 & $10,994^{y}$ & 82 & $11,119^{y}$ & 418 & $10,551^{\mathrm{y}}$ & 661 & & & \\
\hline & $>2$ & $11,017^{\mathrm{y}}$ & 81 & $11,423^{y}$ & 353 & $10,367^{\mathrm{y}}$ & 468 & & & \\
\hline \multirow[t]{4}{*}{ TPEAK (d) } & All & $51^{\mathrm{a}}$ & $50-52^{4}$ & $54^{\mathrm{ab}}$ & $50-58$ & $56^{\mathrm{b}}$ & $51-62$ & 0.041 & 0.59 & $<0.0001$ \\
\hline & 1 & $75^{\mathrm{x}}$ & $73-77$ & $78^{\mathrm{x}}$ & $67-91$ & $77^{\mathrm{x}}$ & 65-91 & & & \\
\hline & 2 & $46^{\mathrm{y}}$ & $45-47$ & $47^{\mathrm{y}}$ & $42-53$ & $50^{y}$ & $42-61$ & & & \\
\hline & $>2$ & $38^{\mathrm{y}}$ & $38-39$ & $42^{\mathrm{y}}$ & $38-46$ & $46^{\mathrm{y}}$ & $40-53$ & & & \\
\hline Animals (no.) & \multicolumn{3}{|c|}{1,071} & 45 & & \multicolumn{2}{|l|}{26} & & & \\
\hline
\end{tabular}

$\stackrel{\bar{c}}{\mathrm{a}, \mathrm{b}}$ Values within a row with different superscripts significantly differ.

ق ${ }^{\mathrm{x}, \mathrm{y}}$ Values within a column with different superscripts significantly differ.

$\stackrel{1}{1}$ Values are model least squares means for healthy $(\mathrm{H})$, affected by mastitis within 30 DIM (MAST), or mastitis within 30 DIM accompanied by any other metabolic disease (MAST+) cows. 
TWIN cows. As TWIN and RP are both risk factors for METR, the lactation curve might be influenced severely by the METR cases.

The incidence of MF in the current study was similar to that reported by DeGaris and Lean (2008) and Fourichon et al. (1999). As in the present study, cows that fail to recover after treatment are often culled before recording of milk yields, thereby biasing the estimation of the effect of MF on milk production (Fourichon et al., 1999). Uncomplicated MF was found to have no effect on milk production variables in early lactation $(\mathrm{Lu}-$ cey et al., 1986; Deluyker et al., 1991), except for the studies by Rajala-Schultz et al. (1999a), which showed decreased milk production in the first 4 to $6 \mathrm{wk}$ and that of Heuer et al. (1999), which found greater firsttest milk production (by $1.3 \mathrm{~kg}$ ) in MF cows. RajalaSchultz et al. (1999a) showed increased milk production in late lactation of 1.1 to $1.7 \mathrm{~kg} / \mathrm{d}$. One of the only studies reporting a long-term effect (Bigras-Poulin et al., 1990) found no difference in M305, suggesting a difference in persistency, which could be confirmed by our study. Milk fever has been linked to many other $\mathrm{MD}$ as a gateway disease facilitating the occurrence of other disorders (Houe et al., 2001; Goff, 2008). Our data strongly support this finding because only complicated MF had a significant effect on milk production variables.

Short-term effects of RP on milk production were described from 5 DIM (Deluyker et al., 1991), up to the first 4 wk (Lucey et al., 1986), 60 DIM (Sheldon et al., 2004), and 100 DIM (van Werven et al., 1992). Conclusions are in accordance with our results for $\mathrm{RP}+$, but not RP, cows. Differences might be explained by the statistical methodology used by other authors that did not always adjust for concomitant periparturient diseases, as discussed by Fourichon et al. (1999). Animals with $\mathrm{RP}$ or $\mathrm{RP}+$ in our data had equal persistency but different MPEAK, resulting in a tendency for a higher M305 in RP compared with RP+ cows. Increased M305 in cows affected by RP was demonstrated by Muller and Owens (1974) and Martin et al. (1986), but these results have not been confirmed since that time (Rajala and Grohn, 1998; Fourichon et al., 1999).

Earlier studies on the effect of METR generally reported conflicting results: either negative (Deluyker et al., 1991; Rajala and Grohn, 1998) or a lack of effect (Fourichon et al., 1999) on short-term milk production. Our data are in agreement with reports of Markusfeld (2003) that showed decreased peak yield and later occurrence of peak. In contrast to Dubuc et al. (2011) and Wittrock et al. (2011), we were able to find a decreased M305 in METR + cows independent of parity. Markusfeld (2003) concluded that primary METR decreased persistency, which was defined as peak yield/180 -
DIM yield $\times 100$, in both primiparous and multiparous cows. We calculated persistency differently (Ehrlich, 2011) but our conclusions were similar: METR and METR + cows decrease milk production at a slower rate compared with $\mathrm{H}$ cows. Uterine infection after calving has been demonstrated to compromise fertility in dairy cows (Opsomer et al., 2000; Melendez et al., 2004), extending the interval calving to conception, which might explain this higher persistency in METR and METR+ cows (Svennersten-Sjaunja and Olsson, 2005).

From both the review of Fourichon et al. (1999) and our results, it can be concluded that short-term effects of KET are relevant. The effect in early lactation differed according to the diagnosis, being based either on clinical signs (Deluyker et al., 1991) or on elevated levels of milk (Dohoo and Martin, 1984b) or blood ketone bodies (Duffield et al., 2009). The latter study showed an altered effect when using different threshold levels at wk 1 or wk 2 after calving for blood ketone bodies (Duffield et al., 2009). The greatest loss in milk yield occurred at blood ketone bodies of 1,400 $(-1.88 \mathrm{~kg} / \mathrm{d})$ and $2,000 \mu \mathrm{mol} / \mathrm{L}(-3.3 \mathrm{~kg} / \mathrm{d})$ in the first and second weeks postpartum, respectively. When confirmed by milk (Dohoo and Martin, 1984a) or blood ketone bodies (Duffield et al., 2009), KET seems to result in a milk yield loss of 1 to $2 \mathrm{~kg} / \mathrm{d}$ at the first DHI test. Reported long-term effects have been more conflicting, from decreased (Gustafsson et al., 1993), to no difference (Dohoo and Martin, 1984a), or increased M305 (Detilleux et al., 1994). A recent study contributed to the explanation for these observations by reporting positive and negative relationships between blood BHBA levels and the projected 305-d mature equivalent (ME305) milk yield in heifers and multiparous cows, respectively (Ospina et al., 2010). In addition, Duffield et al. (2009) reported positive and negative associations between blood BHBA levels and projected ME305 in wk 1 and wk 2 after calving, respectively. As in our study, Gustafsson et al. (1993) and Gustafsson and Emanuelson (1996) reported a flattened lactation curve in ketotic cows (confirmed by milk ketone bodies), which is similar to our results for KET+ cows. A different effect of KET on persistency between primiparous and multiparous cows, as found by Markusfeld (2003), was not confirmed by our results.

The calculated decrease in milk production in early lactation (M60) of $375 \mathrm{~kg}$ in DA+ cows was smaller compared with the loss reported by Detilleux et al. (1997), probably because of a difference in timeframe during which milk production was monitored. We found a higher concurrent disease incidence in the current study $(77 \%)$ compared with that $(54 \%)$ of Detilleux et al. (1997). The latter might be caused by the very intense monitoring of cows in the TMF. Milk loss due to 
DA is thought to occur as soon as $10 \mathrm{~d}$ before diagnosis (Van Winden et al., 2003), which might explain the $30 \%$ of M305 losses occurring before diagnosis, as found by Detilleux et al. (1997). Moreover, M305 milk losses up to $1,016 \mathrm{~kg}$ per lactation have been reported after surgical correction of DA cases (Hamann et al., 2004). Raizman and Santos (2002) did find decreased milk production per day and a tendency for 320 and 544 $\mathrm{kg}$ lower ME305 in primiparous and multiparous cows, respectively. Our results are the first to strengthen the findings of Jorritsma et al. (2008), reporting unchanged M305 production in dairy cows suffering from DA. Bartlett et al. (1997) and Ehrlich (1995) observed that milk production of cows suffering from DA catches up to that of their herdmates by 5 mo after appropriate therapy. Thereafter, DA cows, as in our study, produced more milk than their herdmates. Bias due to low-producing DA cows being culled at a faster rate might have contributed to our finding (and that of others) of a higher persistency in DA+ cows (Bartlett et al., 1997). Both DA and KET nicely demonstrate that the different shape of the lactation curve in uncomplicated and complicated MD, with a slower rise to a lower peak, is compensated for by better persistency in cows that avoid culling during the first 120 DIM.

The effect of MAST has been described and reviewed intensively by Hortet and Seegers (1998) and Seegers et al. (2003). Many studies have focused on the effect of MAST on short-term effects around the moment of diagnosis (Rajala-Schultz et al., 1999b; Wilson et al., 2004) but reports studying the effect of MAST in early lactation on the shape of the lactation curve have been limited. Andersen et al. (2011) reported differences between lactations with records of veterinary clinical MAST treatment and those without records of veterinary treatments. Considering that most MAST cases in the aforementioned study occurred in early lactation, our results confirmed that MPEAK and TPEAK were not altered in uncomplicated MAST. In contrast to the results of Andersen et al. (2011), we were not able to find differences in the slope before peak milk production in second- and older-parity MAST cows. A higher persistency in MAST cows as reported by Appuhamy et al. (2007) was confirmed in our study for MAST+ cows but not by others (Andersen et al., 2011). Overall, short-term effects on milk yield were limited to MAST + cows that, together with the increased persistency, resulted in an overall neutral effect on M305. This is in contrast to studies reporting M305 losses up to about 10\% (Hortet and Seegers, 1998; Wilson et al., 2004; Hagnestam et al., 2007). Milk losses are reported to be largest when MAST occurs around the moment of peak milk yield in primiparous and multiparous cows (Hagnestam et al., 2007). In this transition period study, time to peak milk yield was substantially higher compared with the upper limit of inclusion of MAST (30 DIM), which might have resulted in the observed lack of an effect on M305 compared with previous studies. This implies that in cows that avoid culling up to 120 DIM, long-term effects on M305 due to MAST in the first month of lactation might be limited.

\section{CONCLUSIONS}

The results of the current study demonstrate that lactation curve analysis might contribute substantially to the evaluation of short- and long-term effects of metabolic diseases during the transition period of dairy cows. Milk fever, retained placenta, ketosis, and mastitis mainly affected the lactation curve when accompanied by another MD, whereas metritis and displaced abomasum affected the lactation curve equally with or without another MD. Overall, analysis of long-term effects of MD under the circumstances of this TMF study suggests that a compensatory increase in persistency may partially counteract milk production losses at the time of disease. Further research should focus on the analysis of survival and lifetime production to document in more detail the effect of metabolic diseases in dairy cows as well as possible interactions with effects of pregnancy.

\section{ACKNOWLEDGMENTS}

The authors thank herd manager Martin Moos (Gut Hohen Luckow, Germany) for his full support in providing all necessary information and data from the Gut Hohen Luckow dairy (Germany) and all students that contributed to this study while doing their practical training at the dairy.

\section{REFERENCES}

Andersen, F., O. Osteras, O. Reksen, and Y. T. Grohn. 2011. Mastitis and the shape of the lactation curve in Norwegian dairy cows. J. Dairy Res. 78:23-31.

Appuhamy, J. A. D. R. N., B. G. Cassell, C. D. Dechow, and J. B. Cole. 2007. Phenotypic relationships of common health disorders in dairy cows to lactation persistency estimated from daily milk weights. J. Dairy Sci. 90:4424-4434.

Bartlett, P. C., J. Grymer, H. Houe, and K. E. Sterner. 1997. Cohort study of milk production and days to first insemination following roll-and-toggle LDA correction. Bovine Pract. 31:83-85.

Bigras-Poulin, M., A. H. Meek, and S. W. Martin. 1990. Interrelationships of health problems and age on milk production in selected Ontario Holstein cows. Prev. Vet. Med. 8:3-13.

Chagunda, M. G. G., T. Larsen, M. Bjerring, and K. L. Ingvartsen. 2006. L-Lactate dehydrogenase and $N$-acetyl- $\beta$-D-glucosaminidase activities in bovine milk as indicators of non-specific mastitis. J. Dairy Res. 73:431-440.

Cole, J. B., J. L. Ehrlich, and D. J. Null. 2012. Short communication: Projecting milk yield using best prediction and the MilkBot lac- 
tation model. J. Dairy Sci. http://dx.doi.org/10.3168/jds.20114905.

De Vries, A. 2006. Economic value of pregnancy in dairy cattle. J. Dairy Sci. 89:3876-3885.

Dechow, C. D., and R. C. Goodling. 2008. Mortality, culling by sixty days in milk, and production profiles in high- and low-survival Pennsylvania herds. J. Dairy Sci. 91:4630-4639.

DeGaris, P. J., and I. J. Lean. 2008. Milk fever in dairy cows: A review of pathophysiology and control principles. Vet. J. 176:58-69.

Deluyker, H. A., J. M. Gay, L. D. Weaver, and A. S. Azari. 1991. Change of milk yield with clinical diseases for a high producing dairy herd. J. Dairy Sci. 74:436-445.

Detilleux, J. C., Y. T. Grohn, S. W. Eicker, and R. L. Quaas. 1997. Effects of left displaced abomasum on test day milk yields of Holstein cows. J. Dairy Sci. 80:121-126.

Detilleux, J. C., Y. T. Grohn, and R. L. Quaas. 1994. Effects of clinical ketosis on test day milk yields in Finnish Ayrshire cattle. J. Dairy Sci. 77:3316-3323.

Dohoo, I. R., and S. W. Martin. 1984a. Disease, production and culling in Holstein-Friesian cows. 4. Effects of disease on production. Prev. Vet. Med. 2:755-770.

Dohoo, I. R., and S. W. Martin. 1984b. Subclinical ketosis-Prevalence and associations with production and disease. Can. J. Comp. Med. 48:1-5.

Doll, K., M. Sickinger, and T. Seeger. 2009. New aspects in the pathogenesis of abomasal displacement. Vet. J. 181:90-96.

Drackley, J. K. 1999. Biology of dairy cows during the transition period: The final frontier? J. Dairy Sci. 82:2259-2273.

Dubuc, J., T. F. Duffield, K. E. Leslie, J. S. Walton, and S. J. LeBlanc. 2011. Effects of postpartum uterine diseases on milk production and culling in dairy cows. J. Dairy Sci. 94:1339-1346.

Ducrocq, V., R. L. Quaas, E. J. Pollak, and G. Casella. 1988. Length of productive life of dairy cows. 1. Justification of a Weibull model. J. Dairy Sci. 71:3061-3070.

Duffield, T. F., K. D. Lissemore, B. W. McBride, and K. E. Leslie. 2009. Impact of hyperketonemia in early lactation dairy cows on health and production. J. Dairy Sci. 92:571-580.

Ehrlich, J. 1995. Super-normal milk production subsequent to ventral paramedian abomasopexy. Bovine Pract. 29:83-85.

Ehrlich, J. 2011. Quantifying shape of lactation curves, and benchmark curves for common dairy breeds and parities. Bovine Pract. 45:88-95.

Essl, A. 1998. Longevity in dairy cattle breeding: A review. Livest. Prod. Sci. 57:79-89.

Fetrow, J., T. Ames, R. Farnsworth, S. Godden, P. Rapnicki, S. Stewart, and J. Vrieze. 2004. Minnesota's transition management facility: A private-public partnership in dairy veterinary education and applied research. J. Vet. Med. Educ. 31:368-371.

Fetrow, J., K. V. Nordlund, and H. D. Norman. 2006. Invited review: Culling: Nomenclature, definitions, and recommendations. J. Dairy Sci. 89:1896-1905.

Fourichon, C., H. Seegers, N. Bareille, and F. Beaudeau. 1999. Effects of disease on milk production in the dairy cow: A review. Prev. Vet. Med. 41:1-35.

Fricke, P. M. 2001. Review: Twinning in dairy cattle. Prof. Anim. Sci. $17: 61-67$.

Goff, J. P. 2008. The monitoring, prevention, and treatment of milk fever and subclinical hypocalcemia in dairy cows. Vet. J. 176:50-57.

Gustafsson, A. H., L. Andersson, and U. Emanuelson. 1993. Effect of hyperketonemia, feeding frequency and intake of concentrate and energy on milk yield in dairy cows. Anim. Prod. 56:51-60.

Gustafsson, A. H., and U. Emanuelson. 1996. Milk acetone concentration as an indicator of hyperketonaemia in dairy cows: The critical value revised. Anim. Sci. 63:183-188.

Hadley, G. L., C. A. Wolf, and S. B. Harsh. 2006. Dairy cattle culling patterns, explanations, and implications. J. Dairy Sci. 89:22862296.

Hagnestam, C., U. Emanuelson, and B. Berglund. 2007. Yield losses associated with clinical mastitis occurring in different weeks of lactation. J. Dairy Sci. 90:2260-2270.
Hamann, H., V. Wolf, H. Scholz, and O. Distl. 2004. Relationships between lactational incidence of displaced abomasum and milk production traits in German Holstein cows. J. Vet. Med. A Physiol. Pathol. Clin. Med. 51:203-208.

Heuer, C., Y. H. Schukken, and P. Dobbelaar. 1999. Postpartum body condition score and results from the first test day milk as predictors of disease, fertility, yield, and culling in commercial dairy herds. J. Dairy Sci. 82:295-304.

Hortet, P., and H. Seegers. 1998. Loss in milk yield and related composition changes resulting from clinical mastitis in dairy cows. Prev. Vet. Med. 37:1-20.

Hosmer, D. W., and S. Lemeshow. 2008. Applied Survival Analysis: Regression Modeling of Time to Event Data. 2nd ed. John Wiley \& Son Inc., New York. NY.

Houe, H., S. Ostergaard, T. Thilsing-Hansen, R. J. Jorgensen, T. Larsen, J. T. Sorensen, J. F. Agger, and J. Y. Blom. 2001. Milk fever and subclinical hypocalcaemia-An evaluation of parameters on incidence risk, diagnosis, risk factors and biological effects as input for a decision support system for disease control. Acta Vet. Scand. 42:3-29.

IDF (International Dairy Federation). 1997. Recommendations for presentation of mastitis-related data. Bulletin 321. IDF, Brussels, Belgium.

Jorritsma, R., B. Westerlaan, M. P. R. Bierma, and K. Frankena 2008. Milk yield and survival of Holstein-Friesian dairy cattle after laparoscopic correction of left-displaced abomasum. Vet. Rec. 162:743-746.

Koivula, M., E. A. Mãntysaari, E. Negussie, and T. Serenius. 2005. Genetic and phenotypic relationships among milk yield and somatic cell count before and after clinical mastitis. J. Dairy Sci. $88: 827-833$.

LeBlanc, S. 2010. Monitoring metabolic health of dairy cattle in the transition period. J. Reprod. Dev. 56:S29-S35.

Leroy, J. L. M. R., G. Opsomer, A. Van Soom, I. G. F. Goovaerts, and P. E. J. Bols. 2008. Reduced fertility in high-yielding dairy cows: Are the oocyte and embryo in danger? Part I: The importance of negative energy balance and altered corpus luteum function to the reduction of oocyte and embryo quality in high-yielding dairy cows. Reprod. Domest. Anim. 43:623-632.

Lucey, S., G. J. Rowlands, and A. M. Russell. 1986. Short-term associations between disease and milk yield of dairy cows. J. Dairy Res. 53:7-15.

Markusfeld, O. 2003. What are production diseases, and how do we manage them? Acta Vet. Scand. 44(Suppl. 1):21-33.

Martin, J. M., C. J. Wilcox, J. Moya, and E. W. Klebanow. 1986. Effects of retained fetal membranes on milk yield and reproductive performance. J. Dairy Sci. 69:1166-1168.

Melendez, P., J. McHale, J. Bartolome, L. F. Archbald, and G. A. Donovan. 2004. Uterine involution and fertility of Holstein cows subsequent to early postpartum $\mathrm{PGF}_{2 \alpha}$ treatment for acute puerperal metritis. J. Dairy Sci. 87:3238-3246.

Mostafa, A. S. 2009. Twinning in dairy cattle and its effect on milk yield, lactation length, dry period length and calf performance. Beni-Suef Vet. Med. J. 19:13-18.

Moyes, K. M., T. Larsen, N. C. Friggens, J. K. Drackley, and K. L. Ingvartsen. 2009. Identification of potential markers in blood for the development of sub-clinical and clinical mastitis in dairy cattle at parturition and during early lactation. J. Dairy Sci. 92:5419-5428.

Muller, L. D., and M. J. Owens. 1974. Factors associated with the incidence of retained placentas. J. Dairy Sci. 57:725-728.

Newman, K. D., D. Harvey, and J. P. Roy. 2008. Minimally invasive field abomasopexy techniques for correction and fixation of left displacement of the abomasum in dairy cows. Vet. Clin. North Am. Food Anim. Pract. 24:359-382.

Nielen, M., Y. H. Schukken, D. T. Scholl, H. J. Wilbrink, and A. Brand. 1989. Twinning in dairy cattle: A study of risk factors and effects. Theriogenology 32:845-862.

Opsomer, G., Y. T. Grohn, J. Hertl, M. Coryn, H. Deluyker, and A. de Kruif. 2000. Risk factors for post partum ovarian dysfunction in 
high producing dairy cows in Belgium: A field study. Theriogenology 53:841-857.

Ospina, P. A., D. V. Nydam, T. Stokol, and T. R. Overton. 2010. Associations of elevated nonesterified fatty acids and beta-hydroxybutyrate concentrations with early lactation reproductive performance and milk production in transition dairy cattle in the northeastern United States. J. Dairy Sci. 93:1596-1603.

Raizman, E. A., and J. E. P. Santos. 2002. The effect of left displacement of abomasum corrected by toggle-pin suture on lactation, reproduction, and health of Holstein dairy cows. J. Dairy Sci. 85:1157-1164.

Rajala, P. J., and Y. T. Grohn. 1998. Effects of dystocia, retained placenta, and metritis on milk yield in dairy cows. J. Dairy Sci. $81: 3172-3181$.

Rajala-Schultz, P. J., Y. T. Grohn, and C. E. McCulloch. 1999a. Effects of milk fever, ketosis, and lameness on milk yield in dairy cows. J. Dairy Sci. 82:288-294.

Rajala-Schultz, P. J., Y. T. Grohn, C. E. McCulloch, and C. L. Guard. 1999b. Effects of clinical mastitis on milk yield in dairy cows. J. Dairy Sci. 82:1213-1220.

Rowlands, G. J., and S. Lucey. 1986. Changes in milk yield in dairy cows associated with metabolic and reproductive disease and lameness. Prev. Vet. Med. 4:205-221.

Schefers, J. M., K. A. Weigel, C. L. Rawson, N. R. Zwald, and N. B. Cook. 2010. Management practices associated with conception rate and service rate of lactating Holstein cows in large, commercial dairy herds. J. Dairy Sci. 93:1459-1467.

Seegers, H., C. Fourichon, and F. Beaudeau. 2003. Production effects related to mastitis and mastitis economics in dairy cattle herds. Vet. Res. 34:475-491.

Sheldon, I. M., A. N. Rycroft, and C. Zhou. 2004. Association between postpartum pyrexia and uterine bacterial infection in dairy cattle. Vet. Rec. 154:289-293.
Staples, C. R., W. W. Thatcher, and J. H. Clark. 1990. Relationship between ovarian activity and energy status during the early postpartum period of high-producing dairy cows. J. Dairy Sci. 73:938-947.

Svennersten-Sjaunja, K., and K. Olsson. 2005. Endocrinology of milk production. Domest. Anim. Endocrinol. 29:241-258.

van Werven, T., Y. H. Schukken, J. Lloyd, A. Brand, H. T. Heeringa, and M. Shea. 1992. The effects of duration of retained placenta on reproduction, milk production, postpartum disease and culling rate. Theriogenology 37:1191-1203

Van Winden, S. C. L., R. Jorritsma, K. E. Muller, and J. P. T. M. Noordhuizen. 2003. Feed intake, milk yield, and metabolic parameters prior to left displaced abomasum in dairy cows. J. Dairy Sci. 86:1465-1471.

Wallace, R. L., G. C. McCoy, T. R. Overton, and J. H. Clark. 1996. Effect of adverse health events on dry matter consumption, milk production, and body weight loss of dairy cows during early lactation. J. Dairy Sci. 79(Suppl. 1):205. (Abstr.)

Wilson, D. J., R. N. Gonzalez, J. Hertl, H. F. Schulte, G. J. Bennett, Y. H. Schukken, and Y. T. Grohn. 2004. Effect of clinical mastitis on the lactation curve: A mixed model estimation using daily milk weights. J. Dairy Sci. 87:2073-2084.

Wilson, D. J., Y. T. Grohn, G. J. Bennett, R. N. Gonzalez, Y. H. Schukken, and J. Spatz. 2008. Milk production change following clinical mastitis and reproductive performance compared among J5 vaccinated and control dairy cattle. J. Dairy Sci. 91:3869-3879.

Wittrock, J. M., K. L. Proudfoot, D. M. Weary, and M. A. G. von Keyserlingk. 2011. Short communication: Metritis affects milk production and cull rate of Holstein multiparous and primiparous dairy cows differently. J. Dairy Sci. 94:2408-2412. 